\title{
Heterocyclic terpenes: linear furano- and pyrroloterpenoids
}

\author{
Yonghong Liu, ${ }^{* a}$ Si Zhang ${ }^{a}$ and Pedro J. M. Abreu ${ }^{b}$ \\ Received (in Cambridge, UK) 30th March 2006 \\ First published as an Advance Article on the web 6th June 2006 \\ DOI: $10.1039 / \mathrm{b604586c}$
}

Covering: January 1970 to December 2005

The emphasis of this review is on linear furano- and pyrroloterpenoids, together with their relevant biological activities, source organisms and country of origin. First total syntheses that lead to the revision of structures or stereochemistries have been included, and 206 references are cited.

\section{Introduction \\ 2 Reviews \\ 3 Furanoterpenoids}

${ }^{a}$ Guangdong Key Laboratory of Marine Materia Medica, South China Sea Institute of Oceanology, Chinese Academy of Sciences, Guangzhou, 510-301, China. E-mail: yhliu6@yahoo.com.cn; Fax: +86-20-84451672; Tel: +8620-89023105

${ }^{b} C Q F B / R E Q U I M T E$, Departamento de Química, Faculdade de Ciências e Tecnologia, Universidade Nova de Lisboa, Quinta da Torre, 2829-516, Caparica, Portugal
3.1 Furanosesquiterpenoids

3.2 Furanoditerpenoids

3.3 Furanosesterterpenoids

3.4 Furanotriterpenoids

4 Pyrroloterpenoids

4.1 Pyrrolosesquiterpenoids

4.2 Pyrrolosesterterpenoids and norsesterterpenoids

5 Acknowledgements

6 References

Yonghong Liu obtained his BS and MS degrees from the Changchun College of Traditional Chinese Medicine, China. He then went to Korea, and received his PhD degree from Pusan National University, where he studied the isolation, structure elucidation and structure-activity relationships of biologically active marine natural products under the guidance of Professor Jee H. Jung. He undertook post-doctoral research with Nobutoshi Murakami at Osaka University, Japan, and Pedro Abreu at the New University of Lisbon, Portugal, before returning to China to take a position as a senior scientist at the South China Sea Institute of Oceanology, Chinese Academy of Sciences. His research interests are the isolation and structural elucidation of biologically active secondary metabolites from marine organisms.

Si Zhang received his BS degree from Qingdao Ocean University, followed by an MS degree from the South China Sea Institute of Oceanology, Chinese Academy of Sciences. After receiving his PhD degree from Guangdong University of Traditional Chinese Medicine, China, he is now a professor at the South China Sea Institute of Oceanology, a director of the National (Sanya) Key Research Field-station, and a director of Guangdong Key Laboratory of Marine Materia Medica. His research interests involve the properties, structure and activity of components from marine organisms. He has accomplished the development of two kinds of new marine drugs, and the preclinical study of a new marine drug expected to become a national key drug.

Pedro Abreu graduated in chemistry at the Free University of Brussels (Belgium) in 1975, and returned to Portugal that year to work in the chemical industry. In 1978 he joined the Chemistry Department of the Faculty of Science and Technology (FCT), New University of Lisbon, where he received his PhD in Organic Chemistry in 1987. After a post-doctoral appointment with Professor Takao Yokota at the Faculty of Agriculture, University of Tokyo (1987), he returned to FCT to pursue his teaching and research activities as Professor of Natural Products Chemistry. In the last decade the research interests have been focused on the isolation, characterization, and biological evaluation of natural products from African and Portuguese medicinal plants, and algae of the Portuguese coast.

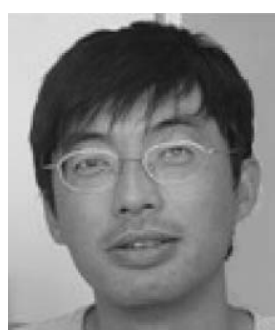

Yonghong Liu

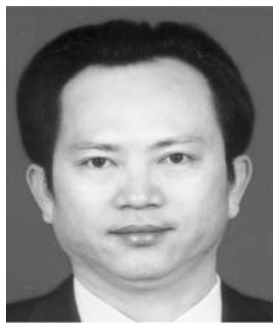

Si Zhang

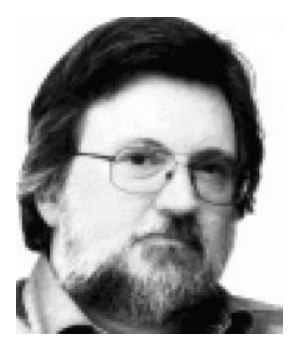

Pedro Abreu 


\section{Introduction}

This review covers the literature from 1970 to 2005 and describes 326 compounds from 206 articles. We show the structures of novel compounds, and previously reported compounds where there has been a structural revision or a newly established stereochemistry. Previously reported compounds for which first syntheses or new bioactivities are described have been referenced, but separate structures have not generally been shown.

\section{Reviews}

A number of reviews have dealt with natural sesquiterpenoids, ${ }^{1}$ diterpenoids, ${ }^{2}$ sesterterpenoids ${ }^{3}$ and triterpenoids. ${ }^{4}$ General reviews include those of marine natural products. ${ }^{5,6}$ Where appropriate, references to other reviews have been included in the following sections.

\section{Furanoterpenoids}

\subsection{Furanosesquiterpenoids}

\subsubsection{Monofuranosesquiterpenoids.}

3.1.1.1 Dendrolasin-type furanosesquiterpenoids. Dendrolasin 1 is a very well-known compound, and four syntheses have been reported..$^{7-10}$ An investigation of the sponge Dysidea herbacea, collected on the Great Barrier Reef, has led to the identification of sesquiterpenoid 2. ${ }^{11}$ A furanosesquiterpene $\mathbf{3}$ has been isolated from the marine sponge Dysidea fragilis (Mont.) from Brittany. ${ }^{12}$ An isomer of dehydrodendrolasin $\mathbf{4}$ has been isolated from the Australian nudibranch Ceratosoma brevicaudatum, collected around the jetty at Rapid Bay, South Australia. ${ }^{13}$ The absolute configuration of (+)-myoporone 5, a furanosesquiterpenoid from Myoporum montanum, ${ }^{14}$ was determined by enantioselective synthesis. ${ }^{15}$ Dictyodendrillins A-C 6-8 were isolated from a South Australian Dictyodendrilla species. ${ }^{16}$ Dictyodendrillin B 7 was prepared by a concise route in $43 \%$ overall yield. ${ }^{17}$

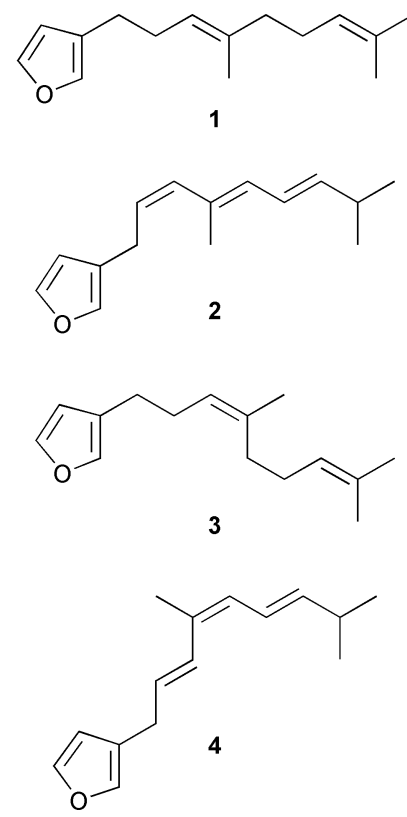<smiles>CC(C)CC(=O)C[C@H](C)CCC(=O)c1ccoc1</smiles><smiles>CC(C)=CCC/C(C)=C/CCC1C(=O)OC2OC21</smiles><smiles>CC(C)=CCC/C(C)=C/CCC1=CC(=O)OC1O</smiles><smiles>CC(C)=CCC/C(C)=C/CCC1=CC(O)OC1=O</smiles>

The $R$ configuration of the hydroxyl group in 4-hydroxymyoporone (athanagrandione) $\mathbf{9}^{18}$ has been established by an interrelationship with (+)-eremoacetal. ${ }^{19}$ The first total synthesis of the stress factor (+)-hydroxymyoporone $\mathbf{9}$ has been established and its absolute configuration reassigned. ${ }^{20}$ The furanoterpene isodehydrodendrolasin $\mathbf{1 0}$ has been obtained from a tropical marine sponge Euryspongia deliculata, collected at Heron Island on the Great Barrier Reef, Australia. ${ }^{21}$ Two homofarnesane lactones, $\mathbf{1 1}$ and 12, and farnesane lactone $\mathbf{1 3}$ have been found in the aerial parts of Gochnatia glutinosa. This is the first time that homofarnesanes have been isolated from plants, although several compounds of this type have been obtained from insects. ${ }^{22}$<smiles>C/C(=C\C=C\C(C)C)C/C=C/c1ccoc1</smiles>

10<smiles>CC(C)=CCC(O)/C(C)=C/CCC1=CC(=O)OC1</smiles><smiles>C=C(CC(O)/C(C)=C/CCC1=CC(=O)OC1)C(C)C</smiles><smiles>C=C(C)CCC(O)/C(C)=C/CCC1=CC(=O)OC1</smiles>

Four sesquiterpenoids 14-17 that are related biosynthetically to ipomeamarone, the well-known sweet potato phytoalexin, have been isolated from the root tissue of sweet potato (Ipomoea batatas) infected with the fungus Cerutocystis fimbriata. ${ }^{23}$ Japanese workers have obtained another phytoalexin, $\mathbf{1 8},{ }^{14}$ from this system 
in the same way. An isodehydrodendrolasin derivative $\mathbf{1 9}$ has been obtained from nudibranchs of the Cantabrian Sea belonging to the Hypselodoris genus, which use this compound as a deterrent against predators. ${ }^{24}$<smiles>CC(C)=CC(=O)CC(C)=CCCC1=CC(=O)OC1</smiles>

14<smiles>CC(C)=CC(=O)C=C(C)CCC(=O)c1ccoc1</smiles><smiles>CC(C)=CC(=O)C=C(C)CCC(=O)c1ccoc1</smiles>

16<smiles>CC(CO)CC(=O)CC(C)(O)CCC(=O)c1ccoc1</smiles>

17<smiles>CC(C)=CC(=O)C/C(C)=C/CCc1ccoc1</smiles><smiles>C=C(C)/C=C/C/C(C)=C/CCc1ccoc1</smiles>

18

19

Six furanosesquiterpenes of the dendrolasin type, 20-25, have been isolated from a cytotoxic extract of the deep ocean tunicate Ritterella rete, ${ }^{25}$ whilst known members of this sesquiterpene group have been found in the Patagonian nudibranch Tyrinna nobilis. ${ }^{26}$ The sesquiterpene $\mathbf{2 6}$ has been isolated from Eremophila forrestii, a medicinal plant in the arid regions of Western Australia. ${ }^{27}$<smiles>CC(C)=CC[C@@H](O)/C(C)=C/CCc1ccoc1</smiles><smiles>CC(C)=CC[C@@H](O)[C@]1(C)O[C@@H]1CCc1ccoc1</smiles><smiles>[Z4]C(=CCCC1=CC(=O)OC1O)C(O)CC=C(C)C</smiles><smiles>COC1C=C(CC/C=C(\C)C(O)CC=C(C)C)C(=O)O1</smiles><smiles>CC(=O)OC(C=C(C)C)CC(C)=CCCC1=CC(=O)OC1</smiles>

3.1.1.2 Other types of furanosesquiterpenoids. Continuing their studies of Australian soft corals, Bowden et al. have isolated twelve structurally related furanosesquiterpenes, 27-38, from Sinularia capillosa. $^{28}$ Compounds 27, 28, and 31 were extremely acid-

sensitive and decomposed on storage. The product $\mathbf{2 8}$ was also isolated from Sinularia firma ${ }^{28}$ The dehydrovernopolyanthofuran 39 has been obtained from Vernonia polyanthes. ${ }^{29}$ Practical syntheses of the anti-inflammatory furanosesquiterpene 36, a metabolite of Sinularia sp., ${ }^{28}$ employ a strategy based on the Claisen rearrangement. ${ }^{30}$<smiles>C=CC(C)=CCCC(C)=Cc1cc(C)co1</smiles>

27<smiles>C=C/C(C)=C/C/C=C(\C)Cc1cc(C)co1</smiles>

31<smiles>C=C/C(C)=C\C/C=C(\C)Cc1cc(C)co1</smiles>

34<smiles>[R]c1coc(CC(C)CCC=C(C)C=C)c1</smiles>

$28 \mathrm{R}=\mathrm{Me}$

$29 \mathrm{R}=\mathrm{CO}_{2} \mathrm{Me}$

$30 \mathrm{R}=\mathrm{CO}_{2} \mathrm{H}$<smiles>[R]c1coc(/C=C(\C)CC/C=C(/C)C=C)c1</smiles>

$32 \mathrm{R}=\mathrm{Me}$

$33 \mathrm{R}=\mathrm{CO}_{2} \mathrm{Me}$

$\mathrm{RO}_{2} \mathrm{C}$<smiles>C=CC(C)=CCCC(C)=Cc1cc(C)co1</smiles>

$\mathrm{RO}_{2} \mathrm{C}$<smiles>C=C/C(C)=C\CCC(C)Cc1cc(F)co1</smiles>

$38 \mathrm{R}=\mathrm{H}$

The furanosesquiterpenoid $\mathbf{4 0}$ was isolated from the Mediterranean alcyonacean Alcyonium pulmatum. ${ }^{31}$ A furanosesquiterpene $\mathbf{4 1}$ has been obtained from the soft coral Lobophytum catalai, which was collected from the Andaman and Nicobar Islands. ${ }^{32}$ Actinolide A $\mathbf{4 2}$ is a sesquiterpenic lactone, found in an extract of the stems of Actinodphne lancifolia. ${ }^{33}$<smiles>C=CC(C)(O)CC/C=C(\C)C(=O)c1cc(C)co1</smiles>

39<smiles>C=C/C(C)=C/CCC(C)(C)[C@H](O)[C@H]1OC(C)=CC1=O</smiles>

41<smiles>C=CC(C)=CCC=C(C)Cc1cocc1C</smiles>

40<smiles>COC1(CC=C(C)CCC=C(C)C)OC(=O)C=C1C</smiles>

Anthecotulide 43 has been isolated from Anthemis cotula. ${ }^{34}$ The isolation and structure determination of two furanosesquiterpenes, $\mathbf{4 4}$ and $\mathbf{4 5}$, from the soft coral Sinularia lochmodes have been described..$^{35}$ Another Sinularia sp. contains the furanosesquiterpene $44 .{ }^{36}$ A sesquiterpene named algoafuran $\mathbf{4 6}$ has been found in an extract of the nudibranch Leminda millecra, collected in Algoa Bay, South Africa ${ }^{37}$ Siphonodictidine $\mathbf{4 7}$ has been synthesized for the first time in a concise and regiocontrolled manner in an overall yield of $25.7 \%{ }^{38}$ Siphonodictidine $\mathbf{4 7}$ is the secondary metabolite of an Indo-Pacific sponge Siphonodictyon sp. ${ }^{39}$ which burrows 


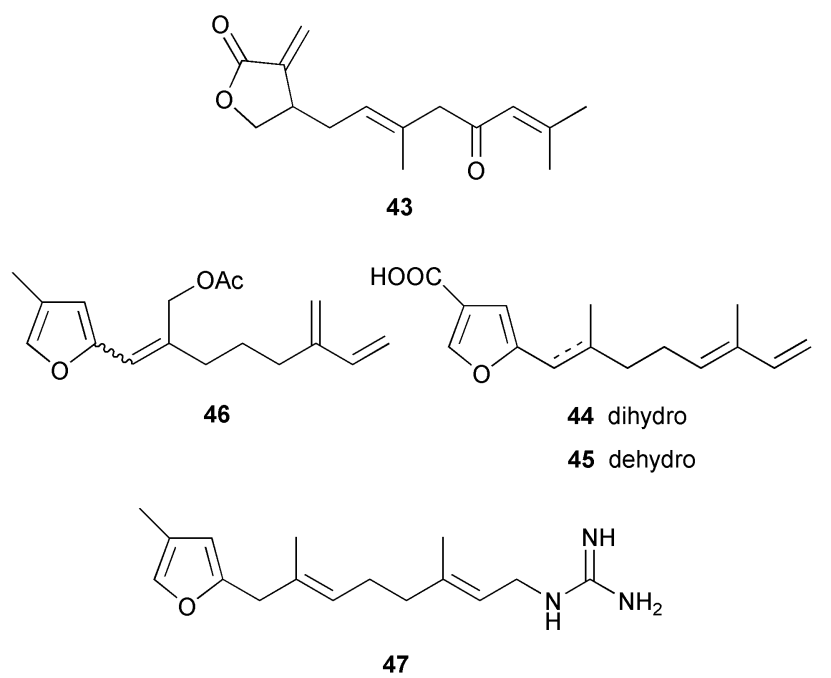

into living coral. Among the members of this class discovered so far, ${ }^{40,41}$ siphonodictidine is remarkable for its biological action, ${ }^{39}$ as it inhibits growth of the coral and appears to be deployed by the sponge to kill coral polyps in its immediate vicinity. Apart from this specific function, which is essential for the survival of the sponge, siphonodictidine exhibits significant antifungal and antimicrobial activity against Gram-positive and Gram-negative bacteria.

The sesquiterpenes $\mathbf{4 8 - 5 0}$ have been isolated from Arctotis arctotoides. ${ }^{42}$ The sesquiterpenoid $\mathbf{5 1}$ has been isolated from the root tissue of sweet potato (Ipomoea batatas) infected with the fungus Cerutocystis fimbriata. ${ }^{23}$ Compound 52, which possesses a sesquiterpenoid skeleton of the caleprunane type, has been isolated from Calea prunifolia. ${ }^{43}$ The structures of cyclonerodiol oxide and epicyclonerodiol oxide, which were isolated from the fungus Trichoderma polysporum, have been shown to be $\mathbf{5 3}$ and 54, respectively. ${ }^{44}$
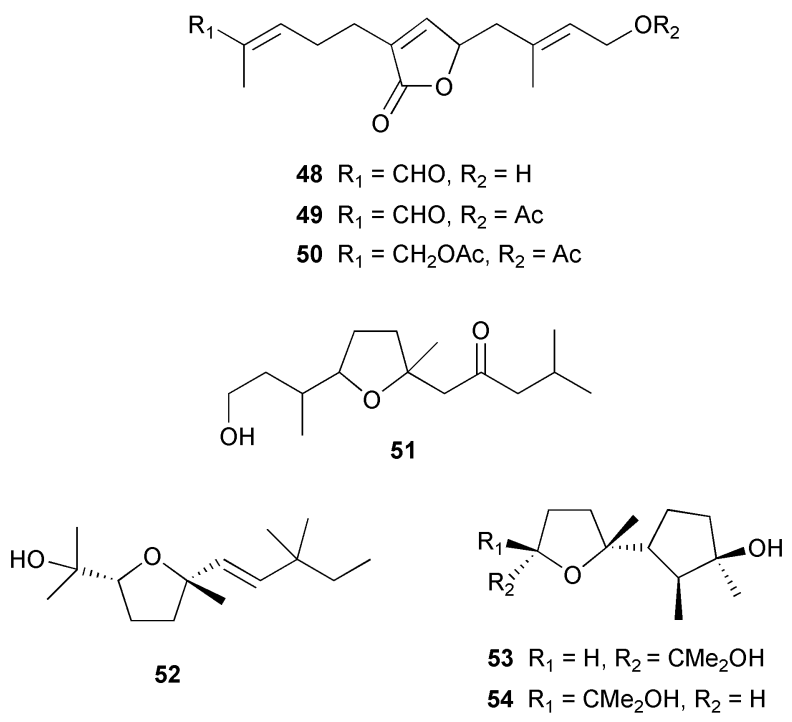

The sesquiterpene 55, related to davanone, has been isolated from Artemisia reptans. ${ }^{45}$ The new nerolidol derivative arteincultone 56 has been isolated from Artemisia inculta. ${ }^{46}$ The essential oil of Artemisia pallens (davana oil) contains more than 50 components, one of which was identified as the nerolidol derivative $\mathbf{5 7 .}{ }^{47}$ A peroxynerolidol derivative, fercoperol $\mathbf{5 8}$, has been found in Ferula communis ssp. communis. ${ }^{48}$ A cyclic sesquiterpene peroxysemiketal, 59, has been isolated from Artemisia maritima. ${ }^{49}$<smiles>C=C[C@]1(C)CCC([C@H](C)C(=O)/C=C(\C)C(=C)C)O1</smiles><smiles>C=C[C@]1(C)CC[C@@H]([C@H](C)C(=O)/C=C/C(C)(C)O)O1</smiles>

57<smiles>C=CC1(C)CCC(C2CCC(C(C)(C)O)OO2)O1</smiles>

58<smiles>C=C[C@]1(C)CC[C@@H]([C@@H](C)[C@]2(O)CC(C(C)C)OO2)O1</smiles>

The davanone-type peroxides epiarteincultone 60 and spiroarteincultone $\mathbf{6 1}$ have been extracted from Artemisia abrotanum. These two metabolites were also prepared synthetically by singlet and triplet oxygen oxidation respectively, and $\mathbf{6 1}$ showed schizoniticidal activity against Plasmodium falciparum. ${ }^{50}$ The essential oil of Santolina oblongifolia contains the cis- and two trans-isomers of $62 .{ }^{51}$ The structures of (+)-myomontanone 63 and isomyomontanone $\mathbf{6 4}$, which are furanosesquiterpenoids from Myoporum montanum, were shown to be the aldol condensation products of $(+)$-myoporone $\mathbf{5}$, which is also present in this plant. ${ }^{14}$<smiles>C=C[C@]1(C)CCC([C@@H](C)C(=O)/C=C/C(C)(C)O)O1</smiles>

60<smiles>C=C[C@]1(C)CCC2(OO[C@@](O)(/C=C/C(C)(C)O)[C@@H]2C)O1</smiles>

61<smiles>CC(C)CC1=C(C(=O)c2ccoc2)C[C@H](C)C1</smiles>

62<smiles>CC(C)CC1=C[C@H](C)C[C@H]1C(=O)c1ccoc1</smiles>

The furanosesquiterpene merrekentrone D $\mathbf{6 5}$ has been found in the roots and rootstocks of Merremia kentrokaulus. ${ }^{52}$ Four furanosesquiterpene $\beta$-hydroxy ketones previously isolated from Myoporum $\mathrm{sp} .{ }^{53}$ have now been assigned complete stereostructures from NMR and X-ray data. The compounds are $(5 R, 7 R, 9 S)$ 9-hydroxy-5,9-dihydromyomontanone 66, $(5 S, 7 R, 9 R)$-9-hydroxy5,9-dihydromyomontanone $\mathbf{6 7}, \quad(5 R, 7 R, 9 R)$-9-hydroxy-5,9-dihydromyomontanone $\mathbf{6 8}$ and $(4 S, 7 S, 8 R)$-4-hydroxy-10,11-didehydro-4,8-dihydromyodesmone 69. 
<smiles>CC(C)CC1=C(C(=O)c2ccoc2)C(=O)C(C)C1</smiles>

65<smiles>CC(C)C[C@]1(O)C[C@H](C)C[C@H]1C(=O)c1ccoc1</smiles>

67<smiles>CC(C)C[C@]1(O)C[C@H](C)C[C@H]1C(=O)c1ccoc1</smiles>

66<smiles>CC(C)C[C@]1(O)C[C@H](C)C[C@H]1C(=O)c1ccoc1</smiles>

68<smiles>CC(C)=CC(=O)[C@H]1[C@@H](C)CC[C@]1(O)c1ccoc1</smiles>

69

Plakortone G $\mathbf{7 0}$ is a highly cytotoxic sesquiterpene, isolated from a Caribbean sponge of the Plakortis genus. ${ }^{54}$ Two furanosesquiterpenoid ketones, dihydrocrassifolone 71 and crassifolone 72, were isolated from the wood essential oil of Myoporum crassifolium from New Caledonia. ${ }^{55}$ The furanosesquiterpene laevidiene $\mathbf{7 3}$ has been isolated from Cadlina iaevis from the Cantabrian Sea (Atlantic Ocean). ${ }^{56}$ The structure 74 has been assigned to a furanosesquiterpenoid obtained from the extract of the aerial parts of Ixiolaena leptolepis. ${ }^{57}$ Two new furanosesquiterpene alcohols, pelseneeriol 175 and pelseneeriol 2 76, have been isolated from the porostome nudibranch Doriopsilla pelseneeri, collected off the Portuguese coast (Atlantic Ocean). ${ }^{58}$ An approach known to give regiospecific and stereospecific reactions has been applied to the first enantioselective synthesis of the natural (-)microcionin 2 77, an example of a molecule containing a trans relationship between the methyl groups. ${ }^{59}$ Microcionin was first<smiles>CC/C=C/C(CC)CCCC1(CC)C=C(CC)C(=O)O1</smiles>

70<smiles>CC(C)=CC(=O)CC1(C)CCCc2ccoc21</smiles>

72<smiles>Cc1ccc(C(C)Cc2cc(C=O)co2)cc1</smiles>

74<smiles>CC1=C[C@@H](O)C[C@H](C)[C@]1(C)CCc1ccoc1</smiles>

76

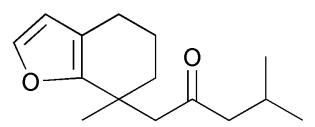

71<smiles>CC(C)=CC=CC1(C)CCCc2ccoc21</smiles>

73<smiles>CC1=C[C@@H](O)C[C@H](C)[C]1CCc1ccoc1</smiles>

75

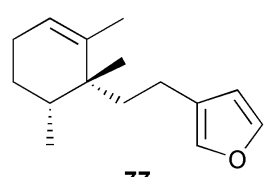

isolated from the sponge Microciona toxystila ${ }^{60}$ and later from the dorid nudibranch molluscs (Dendrodoris grandiflora) growing in contact with them. ${ }^{61} \mathrm{~A}$ second group has also isolated this furanosesquiterpene from another species of dorid nudibranch molluscs, Cadlina luteomarginata. ${ }^{62}$

Tetraenol 78 has been isolated from the relict Chinese plant Tetraena mongolica. ${ }^{63}$ The incubation of small colonies of Sinularia capillosa, freshly collected from Magnetic Island (Australia), with labeled mevalonolactone afforded the furanoquinol 79, containing the label in the terpenoid portion of the sesquiterpene hydroquinone; this confirmed how mevalonate is incorporated into terpenoids in vivo in this soft coral. ${ }^{64}$ The sesquiterpenoid derivative $\mathbf{8 0}$ has been obtained from the roots of Ferula feruloides. ${ }^{65}$ The first total synthesis of cristatic acid $\mathbf{8 1}$ has been reported. ${ }^{66}$ This bioactive sesquiterpene had previously been isolated from the fruiting bodies of the higher mushroom Albatrellus cristatus. ${ }^{67}$ An asymmetric synthesis of $(R)$-sesquilavandulol has been achieved. ${ }^{68}$ Ferula ferulioides also contains the farnesane derivatives $\mathbf{8 2}$ and 83. ${ }^{69,70}$<smiles>CC1=C(CC(=O)c2ccoc2)C(C)(C)C[C@H](O)C1=O</smiles><smiles>C/C(=C\Cc1cc(O)c(C)cc1O)CC/C=C(\C)Cc1cc(C)co1</smiles>

79<smiles>C=CC(C)(CC/C=C(\C)Cc1cc(C)co1)CC(=O)c1ccc(O)cc1O</smiles><smiles>CC(C)=Cc1cc(CCC/C(C)=C/Cc2c(O)cc(C)c(C(=O)O)c2O)co1</smiles><smiles>CC(C)=CCC/C(C)=C/CC/C(C)=C/CC1(O)Oc2cc(O)ccc2C1=O</smiles><smiles>CC(C)=CCC/C(C)=C/CC[C@]1(C)OC(=O)[C@H](C(=O)c2ccc(O)cc2O)[C@@H]1C</smiles>

Four sesquiterpene coumarins 84-87, showing nitric oxide production inhibitory effects, have been found in Ferula fukanensis. ${ }^{71,72}$ The two dihydrofurochromone sesquiterpenes 88 and 89 have been obtained from the roots of Ferula ferulaeoides. ${ }^{73}$ 
<smiles>COc1ccc2c(O)c(C(C)/C(C)=C/C/C=C(\C)Cc3cc(C)co3)c(=O)oc2c1</smiles><smiles>[R][C@@]1(CCC=C(C)Cc2cc(C)co2)c2c(c3ccc(OC)cc3oc2=O)O[C@H]1C</smiles><smiles>COc1ccc2c3c(c(=O)oc2c1)[C@H](C)[C@](C)(CC/C=C(\C)Cc1cc(C)co1)O3</smiles>

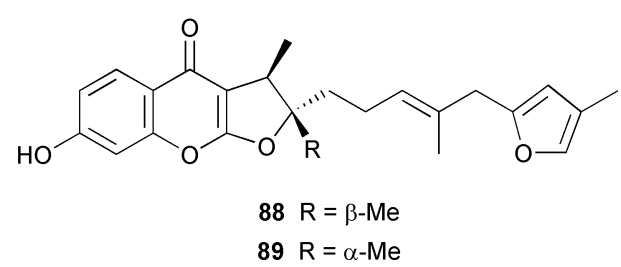

Five sesquiterpene phenylpropanoid derivatives, fukanedones A-E 90-94, were isolated from the roots of Ferula fukanensis.<smiles>COc1ccc(C(=O)[C@H]2C(=O)O[C@](C)(CCC=C(C)CCC=C(C)C)[C@@H]2C)c(O)c1</smiles><smiles>CC(C)=CCC/C(C)=C/CC[C@]1(C)OC(=O)[C@H](C(=O)c2ccc(O)cc2O)[C@@H]1C</smiles><smiles>CC(C)=CC(=O)C=C(C)CCC[C@]1(C)OC(=O)[C@H](C(=O)c2ccc(O)cc2O)[C@@H]1C</smiles>
92<smiles>CC(C)=CC(=O)/C=C(/C)CCC[C@]1(C)OC(=O)[C@H](C(=O)c2ccc(O)cc2O)[C@@H]1C</smiles><smiles>COc1ccc(C(=O)[C@H]2C(=O)O[C@@](C)(CC/C=C(\C)Cc3cc(C)co3)[C@@H]2C)c(O)c1</smiles>

These compounds inhibited NO production and inducible NO synthase gene expression by a murine macrophage-like cell line activated by lipopolysaccharide and recombinant mouse interferon- $\gamma{ }^{74}$

An efficient and stereodefined process is described for the first preparation of a prenyl-benzoylfuranone-type sesquiterpenoid, ( \pm )-3-(2,4-dihydroxybenzoyl)-4,5-dimethyl-5-(4,8dimethylnona-3(E),7(E)-dien-1-yl)tetrahydro-2-furanone $\quad \mathbf{8 3}^{70}$ The synthetic strategy is based on the stereoselective construction of the key quaternary carbon center by nucleophilic addition of organometallic reagents to functionalized ketoamides derived from dihydroxyacetone dimer. ${ }^{75}$ Pallidones B-J 95-103 have been isolated from the EtOAc extracts of the roots of Ferula pallida (Steud.) Korovin (Umbelliferae), which grows in Bulgan Somon of Hovd City, Mongolia. ${ }^{76,77}$ Merrekentrones A 104 and B $\mathbf{1 0 5}$ have been found in the roots and rootstocks of Merremia kentrokaulus. $^{52}$

3.1.2 Bisfuranosesquiterpenoids. A variety of farnesyl/nerolidyl sesquiterpenoids from various plant sources have been identified. These include the lasiospermone derivative 106 from Ursinia nana ${ }^{78}$ and brachymerolide 107 and brachymeral 108 from Brachymeris montana, ${ }^{79}$ one of the woody South African genera of the Anthemideae. The structure of a bisbutenolide, a likely precursor of the acetylenic sesquiterpene freelingyne, obtained from a species of the genus Eremophila, has been determined as 109. ${ }^{80}$ A nerolidol derivative, 110, has been obtained from Ursinia sericeae. ${ }^{81}$ The sesquiterpene bisbutenolides 111 and 112 have been isolated from Eremophila homoplastica. ${ }^{27}$

The work described in a detailed paper by Russell and Sutherland has confirmed the absolute configuration of (-)-ngaione 113, and furthermore it has been conclusively demonstrated that ipomeamarone, a phytoalexin from the sweet potato, is in fact (+)-ngaione 114. ${ }^{82}$ On this basis, it is suggested that the use of the name ipomeamarone should be discontinued. Biosynthetic studies have shown that the three oxygen atoms in (+)-ngaione 114 (= ipomeamarone) are derived from molecular oxygen, not from water nor from the hydroxyl group of farnesol itself. $^{83}$ The absolute configuration of (+)-ipomeamarone $\mathbf{1 1 4}$ has also been independently determined.$^{84} \mathrm{~A}$ furanosesquiterpene, merrekentrone $\mathrm{C} \mathbf{1 1 5}$, has been found in the roots and rootstocks of Merremia kentrokaulus. ${ }^{52}$ A sesquiterpenoids that are related biosynthetically to ipomeamarone which had been infected with the fungus Cerutocystis fimbriata, has the structure $116 .{ }^{23} \mathrm{~A}$ study of the roots of Rehmannia glutinosa led to the isolation of a sesquiterpene 117. ${ }^{85}$ Another species of this genus, Ferula ferulioides, contains farnesane derivatives 118 and $119 .{ }^{11}$

3.1.3 Trisfuranosesquiterpenoids. A sesquiterpenoid 120 related biosynthetically to ipomeamarone 114, the well-known sweet potato phytoalexin, has been isolated from root tissue of sweet potato (Ipomoea batatas) infected with the fungus Cerutocystis fimbriata. ${ }^{23}$ Japanese workers have obtained ${ }^{86}$ another phytoalexin $\mathbf{1 2 1}$, from this system in the same way.

The sesquiterpene chilenone B 122, a trimer of 2-methyl-3(2H)furanone, has been obtained from the red alga Laurencia chilensis, and its structure determined by X-ray analysis. ${ }^{87}$ The synthesis of the difuranosesquiterpene athanasin $\mathbf{1 2 3}$ has enabled its absolute configuration to be established. ${ }^{88}$ Stereochemical studies 
<smiles>COc1ccc2c3c(c(=O)oc2c1)[C@](C)(CC/C=C(\C)CC(=O)CC(C)C)[C@@H](C)O3</smiles><smiles>COc1ccc(C(=O)[C@H]2C(=O)O[C@](C)(CCC/C(C)=C\C(=O)CC(C)C)[C@H]2C)c(O)c1</smiles>

96

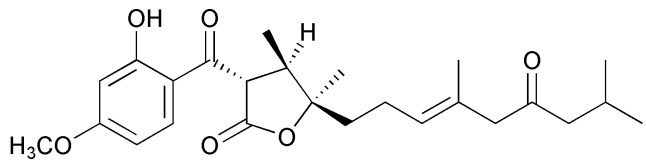

98<smiles>COc1ccc(C(=O)[C@H]2C(=O)O[C@](C)(CCC/C(C)=C/C(=O)CC(C)C)[C@H]2C)c(O)c1</smiles>

100<smiles>COc1cc(O)c2c(=O)c3c(oc2c1)O[C@](C)(CC/C=C(\C)CC(=O)CC(C)C)[C@H]3C</smiles>

102
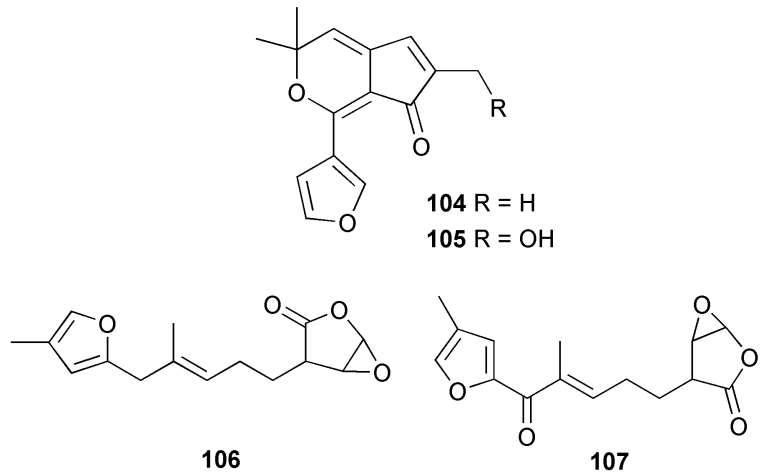

(1)

108

109<smiles>[R]OC(/C=C(\C)Cc1cc(C)co1)Cc1ccoc1</smiles><smiles>[R2]C(/C=C(\C)CC1C=C(C)C(=O)O1)CC1=CC(=O)OC1</smiles>

$110 \mathrm{R}=3$ 年

$111 \mathrm{R}=\mathrm{H}$

$112 \mathrm{R}=\mathrm{AC}$<smiles>COc1ccc(C(=O)[C@H]2C(=O)O[C@](C)(CCC/C(C)=C/C(=O)CC(C)C)[C@@H]2C)c(O)c1</smiles>

97<smiles>COc1ccc(C(=O)[C@H]2C(=O)O[C@](C)(CC/C=C(\C)CC(=O)CC(C)C)[C@@H]2C)c(O)c1</smiles>

99<smiles>COc1ccc(C(=O)[C@H]2C(=O)O[C@@](C)(CC/C=C(\C)CC(=O)C=C(C)C)[C@@H]2C)c(O)c1</smiles>

101<smiles>COc1cc(O)c2c(=O)c3c(oc2c1)O[C@](C)(CC/C=C(\C)C/C=C/C(C)(C)O)[C@H]3C</smiles>

103

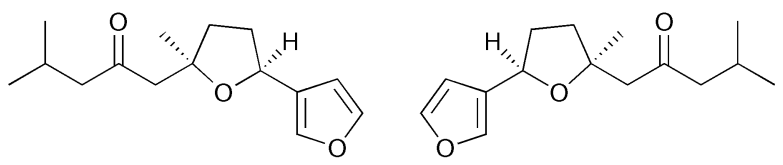

113

114<smiles>CC(C)=CC(=O)CC1(C)OC(c2ccoc2)=CC1=O</smiles><smiles>CC(C)CC(=O)C[C@]1(C)CC[C@@H](C2=CCOC2=O)O1</smiles>

115

116<smiles>[R][C@]1(CC/C=C(\C)Cc2cc(C)co2)OC(=O)[C@H](C(=O)c2ccc(O)cc2O)[C@@H]1C</smiles>

$118 \mathrm{R}=\alpha-\mathrm{Me}$

$119 \mathrm{R}=\beta-\mathrm{Me}$

636 | Nat. Prod. Rep., 2006, 23, 630-651

This journal is (c) The Royal Society of Chemistry 2006 
<smiles>C[C@]1(Cc2cc(CO)co2)CC[C@@H](c2ccoc2)O1</smiles>

120<smiles>Cc1coc(CC2(C)CCC(c3ccoc3)O2)c1</smiles><smiles>CC1OC([C@]2(C)O[C@@H](C3(C)OC=CC3=O)CC2=O)CC1=O</smiles>

122

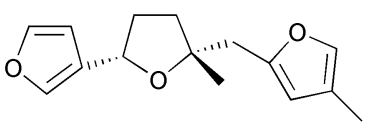

123

on the biosynthesis of homoterpenes derived from nerolidol and geranyllinalool from higher plants, together with mechanistic, phylogenetic, and ecological aspects, have been reported. ${ }^{89}$

3.1.4 Norfuranosesquiterpenoids. The Hawaiian sponge Spongia oceania contains pokepola ester 124, a diester of phosphoric acid in which the alcohols are 5-methylhexan-1-ol and homoserine. The amine of homoserine forms an amide with a trinorfuranosesquiterpenic acid. ${ }^{90}$ The norsesquiterpene $\mathbf{1 2 5}$ has been found in an extract of the aerial parts of Artemisia inculta, collected in three different locations in Egypt. ${ }^{91}$ The sesquiterpenes 126 and 127 have been obtained from Athanasia pinnata. ${ }^{92}$ The aerial part of Calea crocinervosa contains the trisnorsesquiterpene lactone crocinervolide 128. ${ }^{93}$ Compound 129, which possesses the caleprunane skeleton, has been isolated from Calea prunifolia. ${ }^{43}$ The norsesquiterpene 130 has been isolated from Artemisia herba-alba. ${ }^{94}$<smiles>C/C(=C\CCc1ccoc1)CCC(=O)NC(CCOP(=O)(O)OCCCCC(C)C)C(=O)O</smiles><smiles>C=C[C@](C)(O)CCC1OC(=O)C=C1C</smiles>

125<smiles>CC(C)=CC(=O)CC1(C)CCC(=O)O1</smiles>

127<smiles>C=CC(C)(C)/C=C/[C@@]1(C)CCC(=O)O1</smiles>

129<smiles>CCCC(=O)CC(C)(O)CCC(=O)c1ccoc1</smiles>

126<smiles>C=CC(C)(O)CC=CC1(C)CCC(=O)O1</smiles>

128<smiles>C=C[C@]1(C)CCC([C@@H](C)CC(=O)O)O1</smiles>

130

\subsection{Furanoditerpenoids}

3.2.1 Monofuranoditerpenoids. The furan furosolidagonone $\mathbf{1 3 1}$ is among the constituents of Solidago drummondii. ${ }^{95}$ Microglossic acid 132 (from Microglossa zeylanica collected in Sri Lanka) ${ }^{96}$ and 17-(acetoxymethyl)thymifodioic acid 132 (from Baccharis thymifolia $^{97}$ are further examples. It has been suggested that the occurrence of hydroxylated geranylgeraniol derivative 134 with<smiles>CC(C)=CCC(=O)/C(C)=C/CC/C(C)=C/CCc1ccoc1</smiles><smiles>CC(=O)C(CCC=C(C)C)CCCC(CCCc1ccoc1)C(=O)O</smiles>

132<smiles>COCC=C(CCC=C(C)COC(C)=O)CCCC(=CCCc1ccoc1)C(=O)OC</smiles><smiles>CC(=O)OCC(=CCCC1=CC(=O)OC1)CCC=C(CCC=C(C)CO)C(=O)O</smiles>

a butenolide end-group may have taxonomic significance in the classification of the tribe Astereae (Compositae). ${ }^{98}$

The eleganolone diterpenoid $\mathbf{1 3 5}$ was amongst a series obtained from the alga Bifurcaria bifurcata. ${ }^{99}$ Two diterpenes, 136 and 137, isolated from a Western Australian species of Spongia, were obtained as 3:1 mixtures of enantiomers. ${ }^{100}$ The brown alga Bifurcaria bifurcata, collected from Brittany on the Atlantic coast, contained two diterpenoids, bifurcane $\mathbf{1 3 8}$ (which inhibited the development of fertilized sea urchin eggs), and epoxyeleganolactone 139. ${ }^{101}$

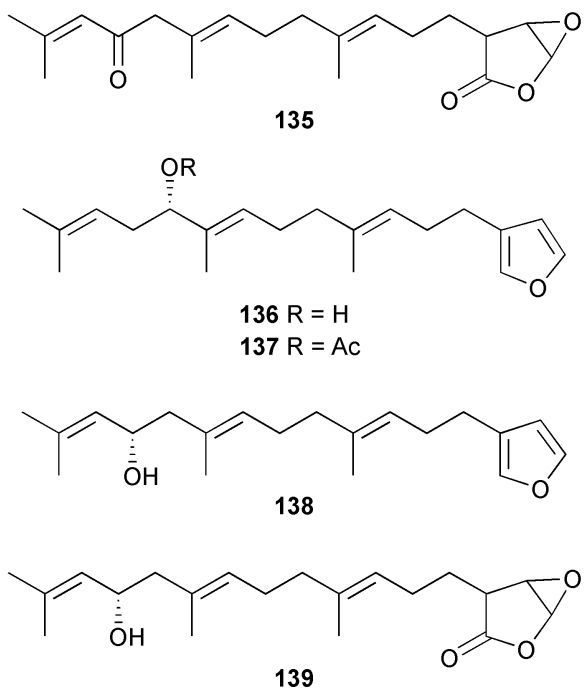

The furanoditerpene 140 was obtained from the Australian sponge Thorectandra choanoides. ${ }^{102}$ The geranylgeraniol derivative 141 has been isolated from a Brazilian medicinal plant, erva-santa, Baccharis ochracea (Asteraceae). ${ }^{103}$ Incanic acid 142 from Conyza incana possesses an $E$ alkene geometry. ${ }^{104}$ Inconyzic acid 143 was obtained from Conyza incana. ${ }^{105}$ 
<smiles>CC(C)=CCC/C(=C/C=C/C(C)=C/CCc1ccoc1)CO</smiles><smiles>CC(C)=CCCC(CCCC(C)=CCCC1=CC(=O)OC1)C(=O)O</smiles>

141<smiles>CC(C)=CCC/C(=C\CC/C(=C/CCc1ccoc1)CO)C(=O)O</smiles>

142<smiles>CC(C)=CCC/C(=C\CC/C(=C/CCC1=CC(=O)OC1)C(=O)O)C(=O)O</smiles>

143

Compound 144 was obtained from specimens of the brown alga Bifurcaria bifurcata from two locations in Brittany. ${ }^{106} \mathrm{Caco}-$ spongionolide C 145 was obtained from the Adriatic sponge Fasciospongia caverrzosa ${ }^{107} \mathrm{~A}$ number of acyclic diterpenoids possess a terminal furan ring, exemplified by conyzaleucolide A 146 obtained from Conyza hypoleuca (Compositae). ${ }^{108}$<smiles>CC(=CCCC12CC(=O)OC1O2)CCC=C(C)CC[C@@H](O)CC(C)C</smiles>

144<smiles>CC(C)CCCC(C)CCCC(C)CCCC1=CC(=O)OC1O</smiles>

145<smiles>CC(C)=CCCC1=CCC(/C(C)=C/CCc2ccoc2)OC1=O</smiles>

Marine organisms continue to yield oxygenated diterpenoids, of which thuridillin 147, from the mollusc Thuridilla hopei, is an example. ${ }^{109}$ Linear diterpenoids have been considered as chemotaxonomic markers in the genus Cystoseira (brown algae). ${ }^{110}$ Halitunal 148 has been isolated from the marine alga Halimeda tuna,${ }^{111}$ and two acyclic furanoditerpene compounds, saurufuran A 149 and B 150, have been obtained from the root of Saururus chinensis. Saurufuran A is a peroxisome proliferator-activated receptor $\gamma(\operatorname{PPAR} \gamma)$ agonist, however, saurufuran B weakly activated PPAR $\gamma{ }^{112}$ Thee geranyl-geraniol derivative 151 has been isolated from from Diplostephium meyenii (Asteraceae). ${ }^{113}$

Lingulatusin 152 and tuxpanolide 153 are geranyl-geraniol derivatives reported from from Aster ligulatus ${ }^{114}$ and Perymenium hintonii, ${ }^{115}$ respectively. An acyclic diterpene- $\gamma$-lactone, hanliuine I 154, has been obtained from Salix matsudan. ${ }^{116}$ The lactone naviculide $\mathbf{1 5 5}$ has been obtained from the liverwort Porella navicularis ${ }^{117}$ whilst some geranyl-linalool glycosides, the capsiansides,<smiles>CC(=O)OC1C=C(C2CC3OC3(CCC=C(C)CCC=C(C)C)C(=O)O2)C(OC(C)=O)O1</smiles>

147<smiles>CC(=O)OC(/C=C(\C)CCC=C(C)C)Cc1cocc2c(C=O)ccc1-2</smiles>

148<smiles>[R]C([R])=CCCC(C)=CCCC(C)=CCc1occc1C</smiles>

$149 \mathrm{R}_{1}=\mathrm{COOH}, \mathrm{R}_{2}=\mathrm{CH}_{3}$

$150 \mathrm{R}_{1}=\mathrm{CH}_{3}, \mathrm{R}_{2}=\mathrm{COOH}$<smiles>CC(C)=CCCC1=CC(C/C(C)=C/CC/C(=C/CO)CO)OC1=O</smiles>

151<smiles>CC(C)(O)[C@H]1CC[C@@H]([C@H]2CC[C@H](CCCC3=CC(=O)O[C@@H]3O)CO2)CO1</smiles><smiles>CC(C)=C[C@H]1OC(=O)/C(=C/CC(O)/C(C)=C/CC/C(C)=C\CO)[C@@H]1O</smiles><smiles>CC(=O)OC(C/C=C1/C(=O)O[C@@H](C=C(C)C)[C@@H]1OC(C)=O)/C(C)=C/CC/C(C)=C\COC(=O)c1ccccc1</smiles>

have been reported from Capsicum plants. ${ }^{118}$ The lactone 156 has been isolated from Melampodium leucanthum. ${ }^{119}$<smiles>C=CC(C)(O)CCC=C(C)CCC=C1CC(C=C(C)C)OC1=O</smiles><smiles>CC(=O)OC/C(C)=C\CCC1=CC(CC(C)(O)C(O)CC/C(C)=C\CO)OC1=O</smiles>

156 
Hanliuin III 157 is a lactone obtained from Salix matsudana. ${ }^{120}$ Cacospongin A $\mathbf{1 5 8}$ was isolated from a Philippine sponge, Cacospongia sp. ${ }^{121}$ Examination of the resinous exudate of a Madia species has yielded madiaol 159. ${ }^{122}$ Examination of the sponge Jaspis splendens afforded (+)-subersin 160, which is an inhibitor of 15-lipoxygenase. ${ }^{123}$<smiles>C=C(C)C(=O)OC/C=C(\C)CC/C=C(\C)CC/C=C1\C(=O)O[C@@H](C=C(C)C)[C@@H]1OC(=O)[O-]</smiles>

3.2.2 Bisfuranoditerpenoids. Caucanolides A-F 161-166 have been isolated from the gorgonian octocoral Pseudopterogorgia bipinnata collected in the south-western Caribbean Sea near Colombia. These compounds showed in vitro antiplasmodial activity against the malaria parasite Plasmodium falciparum. ${ }^{124} \mathrm{~A}$ Korean collection of a sponge of the genus Sarcotragus was found to contain two bisfuranoditerpenoids, sarcotins K 167 and L 168, which displayed weak cytotoxicity. ${ }^{125}$

\subsection{Furanosesterterpenoids}

3.3.1 $\mathrm{C}_{21}$ furanoterpenoids. Many $\mathrm{C}_{21}$ furanosesterterpenes contain a furan ring at both ends of the molecule, such as nitenin 169 and dihydronitenin $\mathbf{1 7 0}$ from Spongia nitens, ${ }^{\mathbf{1 2}}$ and anhydrofurospongin-1 $171^{127}$ and furospongin-1 $\mathbf{1 7 2}^{128}$ from Spongia officinalis and Hippospongia communis, respectively. The compounds 173 and $\mathbf{1 7 4}$ have been detected in a species of the genera Spongia and Leiosella, respectively, ${ }^{129}$ whilst the $\gamma$-lactone furospongolide $\mathbf{1 7 5}^{\mathbf{1 3 0}}$ has been found in Dysidea herbacea.<smiles>CC(=C[C@@H]1CC(=CCCc2ccoc2)C(=O)O1)CCCc1ccoc1</smiles><smiles>C/C(=C\[C@H]1C[C@H](CCCc2ccoc2)C(=O)O1)CCCc1ccoc1</smiles><smiles>CC(=CCCc1ccoc1)CCC=C(C)CCCc1ccoc1</smiles><smiles>C/C(=C\CCc1ccoc1)C[C@@H](O)C[C@H](C)CCCc1ccoc1</smiles>

The sponge Cacospongia scalaris has provided a number of linear $\mathrm{C}_{21}$ difurans, exemplified by cacospongione A 176, cacospongienone A 177, and cacospongienone B 178. ${ }^{131}$ The unsaturated lactone 179, kurospongin, having ichthyotoxic and feeding-deterrent properties, has been isolated from a marine sponge Spongia sp. ${ }^{132}$ Its absolute stereochemistry was established by applying Horeau's method to an alcohol derived from a Grignard reaction on the unsaturated lactone. The untenospongins A 180 and B 181, obtained from a Hippospongia species, ${ }^{133}$ possess<smiles>C=C(C)[C@H](C1C=C(C)C(=O)O1)C1(C)C=C(CCC(C=O)=C(C)C)C(=O)O1</smiles>

161<smiles>CO[C@]1(/C=C(\C)C[C@H]2C=C(CCC(C=O)=C(C)C)C(=O)O2)C=C(C)C(=O)O1</smiles>

164

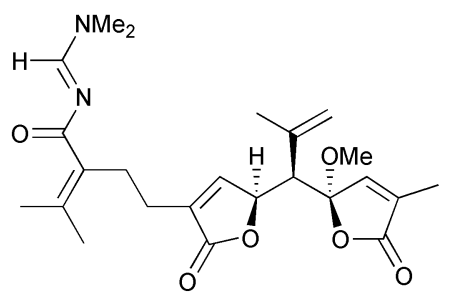

162

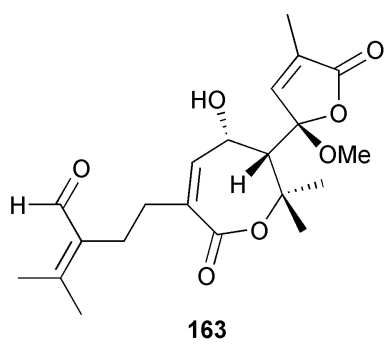

163<smiles>[R]C([R])(/C=C1/C=C(C)C(=O)O1)C[C@H]1C=C(CCC(C=O)=C(C)C)C(=O)O1</smiles>

$165 \mathrm{R}=\mathrm{CH}_{3}, \mathrm{R}_{1}=\mathrm{OCH}_{3}$

$166 \mathrm{R}=\mathrm{OCH}_{3}, \mathrm{R}_{1}=\mathrm{CH}_{3}$<smiles>CC(=CCCc1coc(Cc2ccoc2)c1)CCCC(C)C</smiles>

167<smiles>C/C(=C/CCC(C)C)CCCc1coc(Cc2ccoc2)c1</smiles> 
coronary vasodilating properties. The sponge Carteriospongia flabellifera, collected from the Great Barrier Reef, contains 12,13dehydrofurospongin 1 182. ${ }^{134}$<smiles>CC(/C=C/CC(C)(O)/C=C/Cc1ccoc1)=C\C=C\C(C)=C\[C@@H](O)C/C(C)=C/CCc1ccoc1</smiles>

174<smiles>CC(=CCCC1=CC(=O)OC1)CCC=C(C)CCCc1ccoc1</smiles>

175<smiles>C[C@H](CCCc1ccoc1)CC(=O)C[C@H](C)CCCc1ccoc1</smiles><smiles>C/C(=C/C(=O)C[C@H](C)CCCc1ccoc1)CCCc1ccoc1</smiles><smiles>C/C(=C\C(=O)C[C@H](C)CCCc1ccoc1)CCCc1ccoc1</smiles>

178<smiles>C/C(=C\CCc1ccoc1)C[C@H]1C=C(C/C=C/c2ccoc2)C(=O)O1</smiles><smiles>CC(=CC(O)CC(C)(O)CCCc1ccoc1)CC=Cc1ccoc1</smiles>

180<smiles>CC(=CC(O)CC(C)=CCCc1ccoc1)CC=Cc1ccoc1</smiles>

181<smiles>CC(=CC(O)CC(C)=CCCc1ccoc1)CCCc1ccoc1</smiles>

182

Degraded linear sesterterpenes have been isolated from sponges of the genera Spongia, Carteriospongia and Hippospongia. For example, untenospongin $\mathrm{C} \mathbf{1 8 3}$ has been obtained from an Okinawan Hippospongia sp. ${ }^{135}$ Isonitenin $\mathbf{1 8 4}$ is an additional $\mathrm{C}_{21}$ difuranoterpene from a Spanish collection of Spongia officinalis. ${ }^{136}$ The degradation of tetronic acids with alkaline hydrogen peroxide, to mimic the formation of these compounds, has been reported. ${ }^{137}$
Ent-kurospongin $\mathbf{1 8 5}$ was isolated from a Korean Sarcotragus species. ${ }^{138}$ A Hippospongia sp. from Goa, India, contained entuntenospongin A 186. ${ }^{139}$<smiles>C/C(=C\CCc1ccoc1)CC(=O)CC(C)C/C=C/c1ccoc1</smiles>

183<smiles>CC(=C[C@H]1CC(=CCCc2ccoc2)C(=O)O1)CCCc1ccoc1</smiles><smiles>C/C(=C\CCc1ccoc1)C[C@H]1C=C(C/C=C/c2ccoc2)C(=O)O1</smiles>

185<smiles>C/C(=C\[C@H](O)C[C@](C)(O)CCCc1ccoc1)C/C=C/c1ccoc1</smiles>

186

A $\mathrm{C}_{21}$ difuranoterpene, 187, from a Mediterranean specimen of Spongia virgultosa, was found to be the enantiomer of (-)-untenospongin B from a Japanese Hippospongia sp. ${ }^{133,140}$ Comparison of spectral data suggested that the structure of tetradehydrofurospongin-1 from an Australian Spongia sp. ${ }^{129}$ should be revised from 188 to $187 .{ }^{140}$ The absolute configuration of the $\mathrm{C}_{21}$ difuranoterpene 189, isolated from Fasciospongia cavernosa from the Arabian Sea, ${ }^{141}$ has been determined by synthesis of its enantiomer. ${ }^{142}$

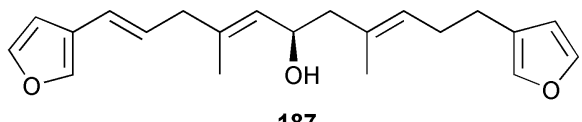

187<smiles>CC(/C=C/Cc1ccoc1)=C\[C@@H](O)C/C(C)=C/CCc1ccoc1</smiles>

188<smiles>CC(=CCCc1ccoc1)CC=C[C@]1(C)CCCc2ccoc21</smiles>

A specimen of Spongia officinalis from La Caleta, Cádiz, Spain, contained two additional minor $\mathrm{C}_{21}$ furanoterpenes, the weakly cytotoxic furospongin-5 190 and cyclofurospongin $2191 .{ }^{143} \mathrm{~A}$ $\mathrm{C}_{21}$ norsesterterpenoid originally reported to have two conjugated double bonds, 192, ${ }^{129}$ has been revised to 193 on the basis of more complete spectroscopic data obtained from a sample isolated from an Australian specimen of Spirastrella papilosa. ${ }^{144}$ The absolute stereochemistry was determined by degradation, and the name (-)-isotetrahydrofurospongin-1 proposed for this bisfuranoterpene. 
<smiles>C/C(=C/CCc1ccoc1)CC(=O)C/C(C)=C/CCc1ccoc1</smiles>

190<smiles>C/C(=C\CCc1ccoc1)CC(=O)CC1(C)CCCc2ccoc21</smiles><smiles>CC(C=CCC(C)(O)C=CCc1ccoc1)=CCCc1ccoc1</smiles><smiles>C/C(=C\CCc1ccoc1)C/C=C/[C@@](C)(O)C/C=C/c1ccoc1</smiles>

193

The suggestion that ircinin 3194 and ircinin 4195 may arise by cleavage of the open forms of the tetronic acids ${ }^{145}$ has been confirmed by the occurrence of the corresponding $\mathrm{C}_{21}$ carboxylic acids 196-200 in Ircinia dendroides. ${ }^{146}$ A synthesis of ircinin 4 195, a metabolite of Ircinia oros, ${ }^{145}$ employed a palladium-catalyzed reaction as the key step. ${ }^{147}$

3.3.2 $\mathrm{C}_{22}$ norsesterterpenoids. $\mathrm{A}_{22} \gamma$-lactone, furodendin $\mathbf{2 0 1}$, has been reported in the sponge Phyllospongia dendyi. ${ }^{148} \mathrm{~A}$ furanoterpene, designated dehydrofurodendin 202, was isolated from two different species of Madagascan sponges of the genus Lendenfeldia, both of which seem to be as yet undescribed. ${ }^{149}$ Dehydrofurodendin $\mathbf{2 0 2}$ has been found to be a potent inhibitor of HIV-1 RT-associated DNA polymerase activity. It should be noted that $\mathbf{2 0 2}$ differs from $\mathbf{2 0 1}$ only in the additional double bond at C-16-C-17, which probably results from oxidation occurring at a late stage in its biosynthesis.<smiles>CC(=CCCc1coc(Cc2ccoc2)c1)CCCC(C)CC(=O)O</smiles>

194<smiles>[R2]C(=O)CC(C)CCC/C(C)=C/CC/C(C)=C\CCc1ccoc1</smiles>
$197 \mathrm{R}=\mathrm{CH}_{3}$<smiles>[R20]C(=O)CC(C)CCC/C(C)=C/CC/C(C)=C/CCc1ccoc1</smiles><smiles>CC(=CCCC1=CCC(=O)OC1)CCC=C(C)CCCc1ccoc1</smiles><smiles>CC(=CCCc1ccoc1)CCC=CC1=CCC(=O)OC1</smiles>

202

Hippospongins E 203 and F 204, from Hippospongia sp. of southern Australian waters, are truncated furanosesterterpenes incorporating diaminoethane. ${ }^{150}$ A Korean collection of a sponge of the genus Sarcotragus was found to contain sarcotins I 205 and $\mathbf{J}$ 206. These compounds have a unique $\mathrm{C}_{22}$ trinorsesterterpene skeleton, and might be degradation products of the corresponding sesterterpenes. ${ }^{125}$<smiles>[R]NCCNC(=O)c1cc(CCC/C(C)=C/c2cc(CCCc3ccoc3)co2)co1</smiles>

A moderately cytotoxic norsesterterpenoid, sarcotin N 207, has been isolated from a Korean Sarcotragus species, and, in the same study, the previously reported sarcotin I 205 was found to have the $21 R$ configuration. ${ }^{138}$ Two trinorsesterterpenoid lactams, the sarcotragins A 208 and B 209, have been isolated from a Sarcotragus species from Jaeju Island (Korea). ${ }^{151}$<smiles>C/C(=C/CCC(C)CC(=O)O)CCCc1coc(Cc2ccoc2)c1</smiles>

195<smiles>[R2]C(=O)CC(C)CCC/C(C)=C\C/C=C(/C)CCCc1ccoc1</smiles>

198<smiles>C/C(=C/C/C=C(\C)CCCC(C)CC(=O)O)CCCc1ccoc1</smiles> 
<smiles>COC(=O)[C@H](O)C/C(C)=C\CC[C@H](C)/C=C/C=C(\C)CCCC1=CC(=O)OC1O</smiles>

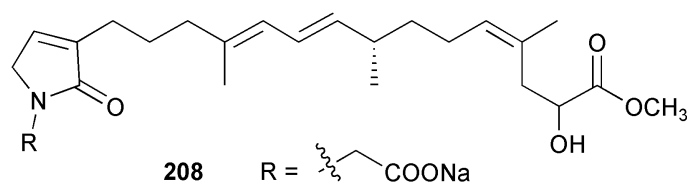<smiles></smiles>

3.3.3 $\mathrm{C}_{24}$ norsesterterpenoids. Konakhin 210, from a Senegalese sponge, represents a degradation product of the corresponding tetronic acid, and is possibly derived from fasciculatin. ${ }^{152}$ The open form of the tetronic acid is a $\beta$-keto acid, and on decarboxylation it generates the enol as the substrate for chloroperoxidase. It is worth noticing that the rate-determining step in many electrophilic halogenations is the formation of the enol, and it is therefore possible that the decarboxylation and halogenation steps are biosynthetically linked. Two similar bisfurans, 211 and 212, have been obtained from a North Adriatic collection of Ircinia oros, ${ }^{153}$ and were found to be toxic to Artemia salina shrimp. Three norsesterterpenoids, 213-215, isolated from an Okinawa Ircinia species, were found to be moderately cytotoxic against the KB cell line. ${ }^{154}$<smiles>C/C(=C\C=C\C(C)CCCC(C)CC(=O)C(O)C(C)Cl)CCCc1ccoc1</smiles>

210<smiles>C/C(=C\CCc1coc(Cc2ccoc2)c1)CCCC(C)CC(=O)C(O)C(C)Cl</smiles>

211<smiles>CC(=CCCC(C)CC(=O)C(O)C(C)Cl)CCCc1coc(Cc2ccoc2)c1</smiles>

212

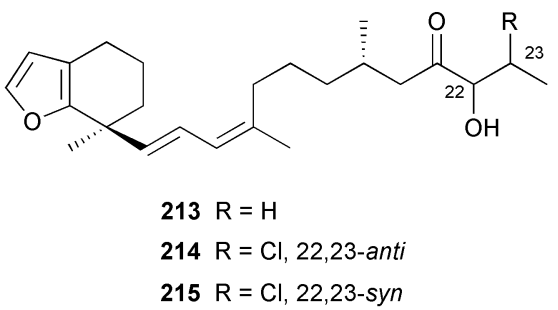

A new $\mathrm{C}_{24}$ furanoterpene, hippospongin D 216, was isolated from a southern Australian collection of the marine sponge Hippospongia sp. ${ }^{150}$ A moderately cytotoxic norsesterterpenoid, sarcotin $\mathrm{O}$ 217, along with two pyrrolonorsesterterpenoids, sarcotrine F 218 and isosarcotrine F 219, were isolated from a Korean Sarcotragus species. ${ }^{138}$<smiles>CCC(=O)c1cc(CCC/C(C)=C/c2cc(CCCc3ccoc3)co2)co1</smiles>

216<smiles>CCCCCCCC(C)=CC=C[C@@H](C)CCC=C(C)CC(O)C(O)C(C)=O</smiles>

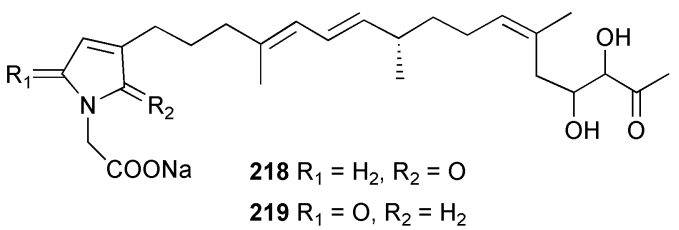

3.3.4 $\mathrm{C}_{25}$ non-conjugated tetronic acid furanosesterterpenoids. Palinurin 220 is a linear furanosesterterpene previously reported from the Mediterranean sponge Ircinia variabilis. ${ }^{155}$ Ircinic acid 221 was isolated from marine sponge Ircinia sp. collected from Fiji and also found from a Truck lagoon sponge. ${ }^{156}$ Palominin 222 is another geometrical isomer obtained ${ }^{157}$ from a Caribbean Ircinia species. Like many of these compounds from sponges, it possesses ichthyotoxic properties and thus may have a role in protecting the sponge against predators.
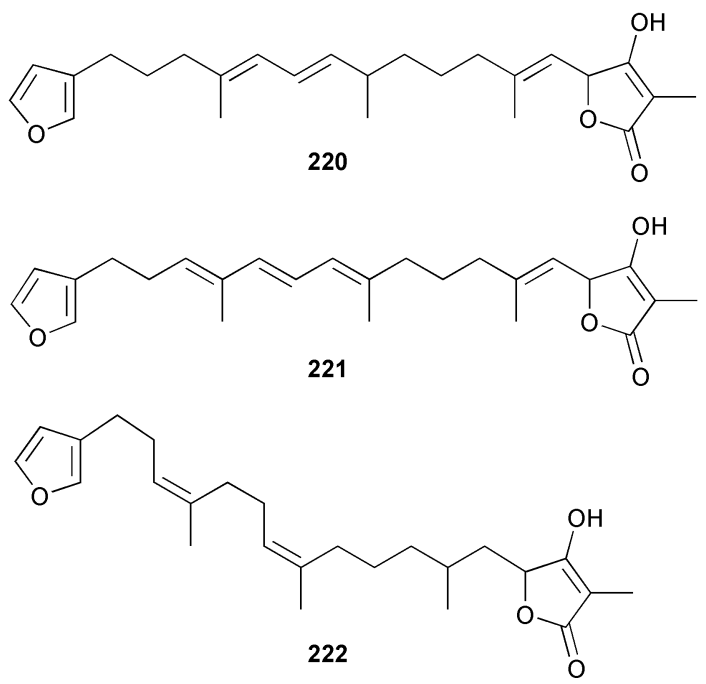

Compound 223 has been reported as a constituent of Psarnrnocinia rugosa. ${ }^{158}$ The bisfurans spongionellin 224 and dehydrospongionellin have been described in extracts of a Spongionella species. ${ }^{159}$ The okinonellins A 225 and B 226 are furanosesterterpenes from another Spongionella species, which inhibit celldivision in fertilized starfish eggs and again may play a role in marine chemical ecology. ${ }^{160}$ Okinellin A 225, isolated from the Okinawan marine sponge Hippospongia sp., is probably identical to hippospongin, and possesses antispasmodic activity. ${ }^{161}$ Both the $8 S, 21 S, 22 S, 23 R$ - and $8 R, 21 S, 22 S, 23 R$-isomers of okinonellin $B$ 226, which is a cytotoxic and antispasmodic agent from Spongionella sp., have been synthesized, but neither has the same optical rotation as the natural product. ${ }^{162}$ 
<smiles>CC(=CC=C[C@@H](C)CCCc1ccoc1)CCC=C(C)CC1OC(=O)C(C)=C1O</smiles><smiles>CC(=CCCc1coc(Cc2ccoc2)c1)CCC=C(C)CC1OC(=O)C(C)=C1O</smiles><smiles>C=C(CCC/C(C)=C/C=C/C1(C)CCCc2ccoc21)CC1OC(=O)C(C)=C1O</smiles><smiles>C=C(CCC/C(C)=C/C=C/C(C)CCCc1ccoc1)C[C@@H]1OC(=O)[C@H](C)[C@H]1O</smiles>

A tetronic acid with antimicrobial activity, 227, has been isolated from an Australian sponge of the Psammocinia genus. ${ }^{163}$ Isopalinurin 228, which is a mild protein phosphatase inhibitor, was obtained from a South Australian Dysidea species. ${ }^{164}$<smiles>CCCCCC(C)=CC=CC(C)CC1OC(=O)C(C)=C1O</smiles><smiles>C/C(=C\CCc1ccoc1)CCCC(C)/C=C/C=C(\C)CC1OC(=O)C([18O])=C1O</smiles><smiles>CC(=CC=CC(C)C[C@H]1OC(=O)C(C)=C1O)CCCc1coc(Cc2ccoc2)c1</smiles>

Cometin A 229 contains two furan rings and is another product obtained from Australian sponges. ${ }^{165}$ Three cytotoxic furanosesterterpenoids, sacotins A-C 230-232, were reported from a specimen of Sarcotragus sp. collected at Cheju Island, Korea. ${ }^{166}$ The cytotoxic sesterterpenoids epi-sacotin A 233, and sarcotins F 234 and M 235, were isolated from same Korean Sarcotragus species. ${ }^{125}$ Epi-sacotin F $\mathbf{2 3 6}^{138}$ was found in two Korean Sarcotragus species.

Cytotoxic furanosesterterpenes palinurin $220{ }^{155}$ and isopalinurin $228{ }^{164}$ were re-isolated from a marine sponge Psammocinia sp. collected from Ulleung Island, Korea. The configuration at C-21 has not been previously investigated, and it has now been determined to be $R$ on the basis of CD analysis. ${ }^{167}$
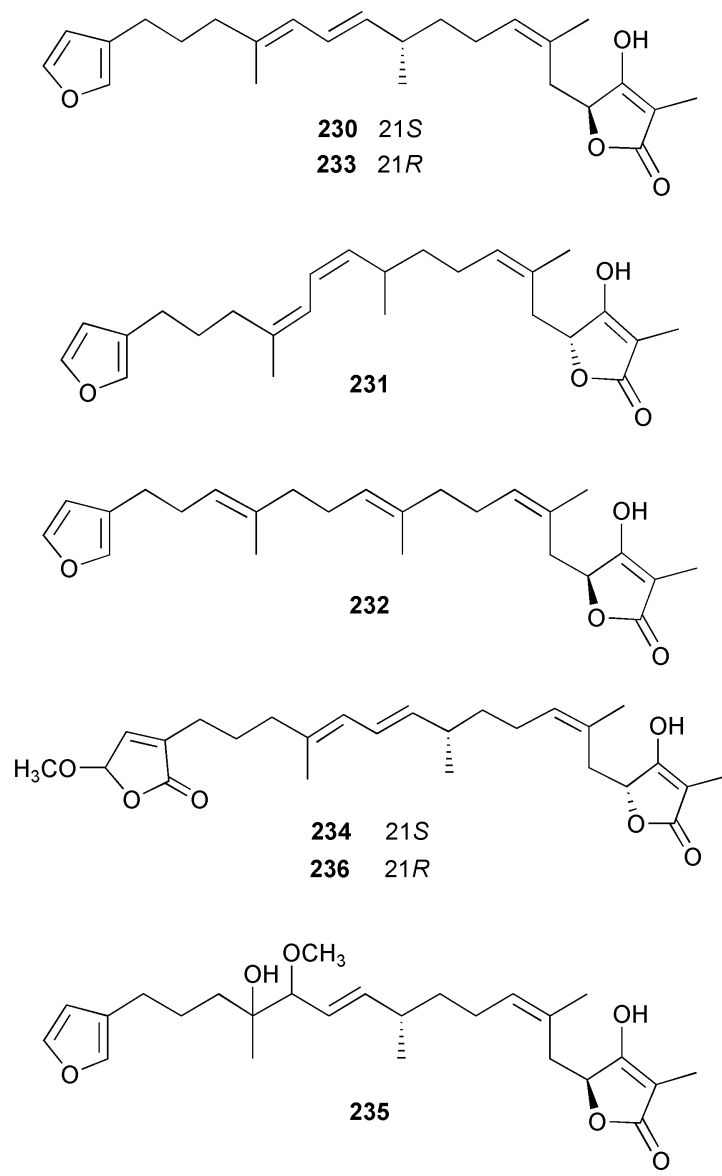

3.3.5 $\mathrm{C}_{25}$ conjugated tetronic acid furanosesterterpenoids. Marine organisms, particularly sponges, have continued to provide a source of linear sesterterpenoids. The terminal units often comprise either a furan or a tetronic acid moiety. Two isomeric linear difuranosesterterpenes, ircinin 1237 and ircinin 2 238, were obtained from the sponge Ircinia oros, and contain a second furan ring. ${ }^{168}$ Quite a number of these compounds contain a tetronic acid moiety and show strong antibiotic activity against Staphylococcus aureus. These are exemplified by variabilin 239 from Ircinia variabilis, ${ }^{169}$ its double-bond isomer strobilinin $\mathbf{2 4 0}$ from Ircinia strobilina,${ }^{170}$ and fasciculatin 241 from Ircinia fasciculata.${ }^{171}$<smiles>CC(=CCCc1coc(Cc2ccoc2)c1)CCCC(C)C=C1OC(=O)C(C)=C1O</smiles><smiles>CC1=C(O)/C(=C/C(C)CC/C=C(/C)CCCc2coc(Cc3ccoc3)c2)OC1=O</smiles>

Compounds 242 and 243 occur in Ircinia dendroides. ${ }^{146}$ Variabilin 239 and its double-bond isomers are quite widespread. As well as being obtained from sponges of the genus Ircinia, it has now been found in the New Zealand sponge Sarcotragus, ${ }^{172}$ whilst 22deoxyvariabilin $\mathbf{2 4 4}$ has been found in a Thorecta species collected 
off the Bay of Islands, New Zealand. ${ }^{173}$ In an antimicrobial assay, 22-deoxyvariabilin inhibited the growth of Staphylococcus aureus, Bacillus subtilis, and Candida albicans. NMR studies of ircinins 1237 and 2 238, two difuranosesterterpenes isolated from a Fijian Ircinia sp., have been reported. ${ }^{156}$ Two additional oxygenated furanosesterterpenes, 245 and 246, have been described from an Ircinia species collected from Kaikoura, New Zealand. ${ }^{174}$<smiles>CC(=CCCC(C)C=C1OC(=O)C(C)=C1O)CCC=C(C)CCCc1ccoc1</smiles><smiles>CC(=CCCC(C)=CCCC(C)=CCCc1ccoc1)C=C1OC(=O)C(C)=C1O</smiles><smiles>[Z10]C(/C=C/C=C(\C)CCCc1ccoc1)CCC[C@H](C)/C=C1\OC(=O)C(C)=C1O</smiles><smiles>[R4]C(=CCCC(C)=CCCc1ccoc1)CCCC(C)C=C1OC(=O)C(C)=C1O</smiles><smiles>CC(=CCCC(C)C=C1OC(=O)C(C)=C1O)CCC=C(C)CCCc1ccoc1</smiles>

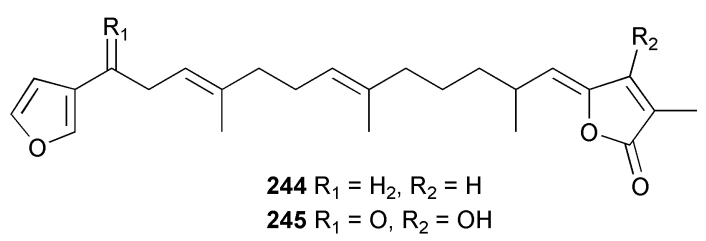<smiles>CC(=CCCC(C)(O)CCCc1ccoc1)CCCC(C)C=C1OC(=O)C(C)=C1O</smiles>

Variabilin is readily available from Ircinia, Psammocinia, and Sarcotragus species, and because it shows promising activity as an antiviral agent, its chemistry has been explored. ${ }^{175}$ The tetronic acid moiety acts as a sensitizer for the production of singlet oxygen, which then reacts with the furan to give a range of products including hydroxybutenolides. The 22- $O$-methyl derivative is stable, and although it retains antiviral activity, it was not possible to dissociate the cytotoxicity from the antiviral activity. The decomposition of these furans has stimulated further studies ${ }^{176}$ on the regioselective oxidation of 3-alkylfurans with singlet oxygen. (18S)-Variabilin $\mathbf{2 4 7}$ is a widespread member of this series, and its absolute stereochemistry and that of some related tetronic acids have been established. ${ }^{177,178}(18 R)$-Variabilin 248 has been isolated from the sponge Ircinia fefix from Colombia. ${ }^{179}$ Two sesterterpenoids, 249 and 250, isolated from an Okinawa Ircinia species, were found to be moderately cytotoxic. ${ }^{154}$<smiles>[Z10]C=C(C)CCC[C@H](C)C=C1OC(=O)C(C)=C1O</smiles><smiles>[Z16]C(=CCCC(C)=CCCc1ccoc1)CCC[C@H](C)C=C1OC(=O)C(C)=C1O</smiles><smiles>CC(=CC=C[C@]1(C)CCCc2ccoc21)CCC[C@@H](C)C=C1OC(=O)C(C)=C1O</smiles>

$24912 Z$

$25012 E$

A re-investigation of the structure of strobilinin, originally isolated from Ircinia strobilina, ${ }^{170}$ revealed that it consisted of two geometrical isomers, 251 and $\mathbf{2 5 2} .{ }^{180}$ The structures of $(18 S)$ ircinin-1 237, ${ }^{168}(18 S)$-ircinin $2238,{ }^{168}$ and strobilinins 251 and 252 have been tentatively assigned. ${ }^{178}$ Two additional geometrical isomers, $(8 Z, 13 Z, 20 Z)$-strobilinin 253 and $(7 Z, 13 Z, 20 Z)$ felixinin 255, were partially characterized after isolation as their 22- $O$-acetates from Columbian specimens of $I$. felix, I. strobilina and I. campana. ${ }^{181}(8 Z, 13 Z, 18 S, 20 Z)$-Strobilinin 254 and $(7 E, 12 Z, 18 S, 20 Z)$-variabilin 256 from a Maltese specimen of $I$. oros were characterized as their corresponding 22- $O$-methyl derivatives. ${ }^{182}$ The first asymmetric synthesis of the marine furanosesterterpene tetronic acid $18 S$-variabilin $\mathbf{2 5 6}$, from the sponge Ircinia variabilis, has been reported. ${ }^{183}$ An efficient and stereodefined process is employed, featuring lipase-catalyzed asymmetric desymmetrization of two types of propanediol precursors incorporating the terpene skeleton.<smiles>CC(=CCC[C@@H](C)C=C1OC(=O)C(C)=C1O)CCC=C(C)CCCc1ccoc1</smiles><smiles>CC(=CCC[C@@H](C)C=C1OC(=O)C(C)=C1O)CCC=C(C)CCCc1ccoc1</smiles>

252 
<smiles>CC(=CCCC(C)C=C1OC(=O)C(C)=C1O)CCC=C(C)CCCc1ccoc1</smiles><smiles>CC1=C(O)/C(=C/[C@H](C)CC/C=C(/C)CCC/C(C)=C\CCc2ccoc2)OC1=O</smiles>

254<smiles>CC(=CCCc1ccoc1)CCC(C)=CCC(C)C=C1OC(=O)C(C)=C1O</smiles>

Three new furanosesterterpenes, 257-259, and the known cytotoxic compounds $(7 E, 12 E, 18 R, 20 Z)$-variabilin, $(8 E, 13 Z$, $18 R, 20 Z)$-strobilinin, ( $7 E, 13 Z, 18 R, 20 Z)$-felixinin [also known as $(7 E, 13 Z, 18 R, 20 Z)$-variabilin], $(8 Z, 13 Z, 18 R, 20 Z)$-strobilinin, and $(7 Z, 13 Z, 18 R, 20 Z)$-felixinin, were isolated from a Korean marine sponge, Psammocinia sp. These compounds were evaluated for cytotoxicity against a panel of five human tumor cell lines, and most of the compounds showed toxicity to SK-MEL$2 .{ }^{167}$ A mixture of $(8 E, 13 Z, 20 Z)$-strobilinin and $(7 E, 13 Z, 20 Z)$ felixinin displayed significant inhibition of DNA replication and a moderate antioxidant profile. ${ }^{184}$

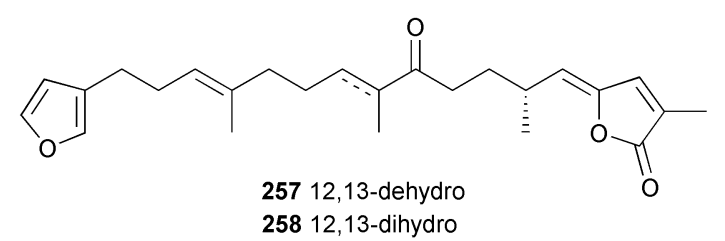<smiles>COC1C=C(CCCC(C)CCCC(C)CC/C=C(C)/C=C2\OC(=O)C(C)=C2O)C(OC)O1</smiles>

Eight cytotoxic furanosesterterpenoids, namely ircinins 1and 2, sacotins D 260 and E 261, ${ }^{166}$ sacotins G 262 and $H$ 263, ${ }^{125}$ $(7 E, 12 E, 18 R, 20 Z)$-variabilin, and $(8 E, 13 Z, 18 R, 20 Z)$-strobilinin, ${ }^{138}$ were reported from a specimen of Sarcotragus sp. collected off Cheju Island, Korea. 22-Deoxy-23-(hydroxymethyl)variabilin 264 was isolated from both the South African nudibranch Hypselodoris capensis and the sponge Fasciospongia sp. on which it was feeding. ${ }^{185}$

3.3.6 $\mathbf{C}_{25}$ monofuranosesterterpenoids. Simple furans are exemplified by furospongin 3265 and furospongin 4 266, identified from Spongia officinalis. ${ }^{145}$ The sponge Spongia idia (Leiosella idia) from Pt Loma, San Diego, contained idiadione 267. ${ }^{186}$ Idiadione was found to be toxic to the sea star Pisaster giganteus, a brine shrimp Artemia sp., and the ectoproct Membranipora memoranacea, and<smiles>CC1=C(O)/C(=C\[C@H](C)CCC/C(C)=C/CCc2coc(Cc3ccoc3)c2)OC1=O</smiles><smiles>CC1=C(O)/C(=C\[C@H](C)CC/C=C(\C)CCCc2coc(Cc3ccoc3)c2)OC1=O</smiles><smiles>CO[C@@]1(Cc2ccoc2)C=C(CC/C=C(\C)CCC[C@H](C)/C=C2\OC(=O)C(C)=C2O)C(=O)O1</smiles>

262<smiles>CO[C@@]1(Cc2ccoc2)C=C(CCC/C(C)=C\CC[C@H](C)/C=C2\OC(=O)C(C)=C2O)C(=O)O1</smiles><smiles>CC(=CCCc1ccoc1)CCCC(C)=CCCC(C)C=C1C=C(CO)C(=O)O1</smiles>

also immobilized the larvae of the red abalone Haliotis rufescens in sea-water. Idiadione $\mathbf{2 6 7}$ was synthesized from citronellal, establishing the stereogenic centre as $S .{ }^{187}$

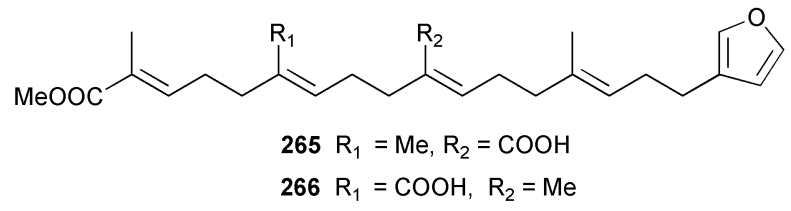<smiles>C/C(=C\CCC(C)CC(=O)CC(C)CCCc1ccoc1)CC(=O)CC(C)C</smiles>

267

The sesterterpenoid 268, obtained from the Caribbean sponge Thorecta horridus, ${ }^{188}$ possessed a marked inflammatory activity, inducing the release of histamine and causing oedema in the paw of test animals. In contrast, thorectolide mono-acetate 269, obtained from a New Caledonian marine sponge of the genus $\mathrm{Hyr}$ tios, ${ }^{189}$ possessed anti-inflammatory properties. The epoxyfuran carboxylic acid $\mathbf{2 7 0}$ has been isolated from a Western Australian Spongia species. ${ }^{100}$ A cytotoxic sesterterpenoid, cacospongionolide D 271, was isolated from Fasciospongia cavernosa from the Bay of Naples. ${ }^{190}$ A specimen of Spongia officinalis from La Caleta, Cádiz, Spain, contained demethylfurospongin 4 272, which was weakly cytotoxic against the $\mathrm{P}-388$ cell line. ${ }^{143} \mathrm{~A}$ linear $\mathrm{C}_{25}$ furanoterpene, furospinosulin 1 273, has been isolated from Ircinia spinosula. ${ }^{191}$ The bicyclic lactone astakolactin $\mathbf{2 7 4}$ was obtained from specimens of Cacospongia scalaris collected from the Gulf of Astakos, Greece. ${ }^{192}$ 
<smiles>CC(=O)O[C@H]1OC(=O)C=C[C@H]1[C@H]1CC=C(CCC/C(C)=C/CC/C(C)=C/CC/C(C)=C/CC/C=C(\C)CC/C=C(\C)CC/C=C(\C)CCC=C(C)C)C(O)O1</smiles>

269<smiles>CC(=CCCc1ccoc1)CCC=C(C)CCC1OC1(C)CCC=C(C)C(=O)O</smiles><smiles>CC(C)=CCC/C(C)=C/CC/C(C)=C/CCC1=CCC(C2=CC(=O)O[C@@H]2O)OC1</smiles>

271<smiles>CC(=CCCC(=CCCC(C)=CCCc1ccoc1)C(=O)O)CCC=C(C)C(=O)O</smiles>

272<smiles>CC(C)=CCC/C(C)=C/CC/C(C)=C/CC/C(C)=C/CCc1ccoc1</smiles>

273<smiles>C/C(=C\CC/C=C1\CC[C@H](C)[C@@H](C)C(=O)OC1)CC/C=C(\C)CCc1ccoc1</smiles>

3.3.7 $C_{25}$ bisfuranosesterterpenoids. Luffarin $R \quad 275$ has been isolated ${ }^{193}$ from Luffariella geometrica. A cytotoxic sesterterpenoid, (6Z)-luffarin-V 276, has been isolated from Fasciospongia cavernosa from the Bay of Naples. ${ }^{190}$<smiles>CC(C)=CC1C/C(=C/CC/C(C)=C/CC/C(C)=C/C[C@H](O)C2=CC(=O)OC2)C(=O)O1</smiles>

275<smiles>CC(C)=CC1C/C(=C/CC/C(C)=C/CC/C(C)=C/CCC2=CC(=O)OC2)C(=O)O1</smiles>

276

3.3.8 $\mathrm{C}_{25}$ trisfuranosesterterpenoids. Three $\mathrm{C}_{25}$ furanoterpenes, hippospongins A-C 277-279, were isolated from a southern Australian collection of the marine sponge Hippospongia sp. Hippospongin A $\mathbf{2 7 9}$ was found to be a mild antibiotic, inhibiting the growth of Staphylococcus aureus. ${ }^{150}$<smiles>CC(CCCc1coc(CC(C)C(=O)O)c1)Cc1cc(CCCc2ccoc2)co1</smiles>

277<smiles>[R8][R8]</smiles><smiles>C/C(=C\c1cc(CCCc2ccoc2)co1)C(=O)NCCN</smiles>

3.3.9 Salts of sesterterpenoids. Four unstable sulfate esters of furanosesterterpenes, 280-283, were obtained from Ircinia variabilis and I. oros of the northern Adriatic Sea. ${ }^{194}$ A Californian sponge of the family Halichondriidae contained sulfated sesterterpene halisulfate $3 \mathbf{2 8 4}$, ${ }^{195}$ which possesses antimicrobial and anti-inflammatory properties. The 22-O-sulfates 285 and 286 of palinurin and fasciculatin, which were toxic to brine shrimp Artemia salina, were isolated from Ircinia variabilis and I. fasciculata, respectively. ${ }^{196}$ A sodium salt of the pyrroloterpenoid sarcotragin A $\mathbf{2 0 8}$ was isolated from a Sarcotragus sp. collected from Jaeju Island in Korean waters. ${ }^{151}$ A sodium salt of trinorsesterterpene acid sarcotin I $\mathbf{2 0 5},{ }^{125}$ and the sodium salts of four pyrroloterpenoids, sarcotrines E $\mathbf{2 8 7}$ and F 288 and isosarcotrines E $\mathbf{2 1 8}$ and F 219, ${ }^{138}$ were isolated from the Korean sponge Sarcotragus sp.
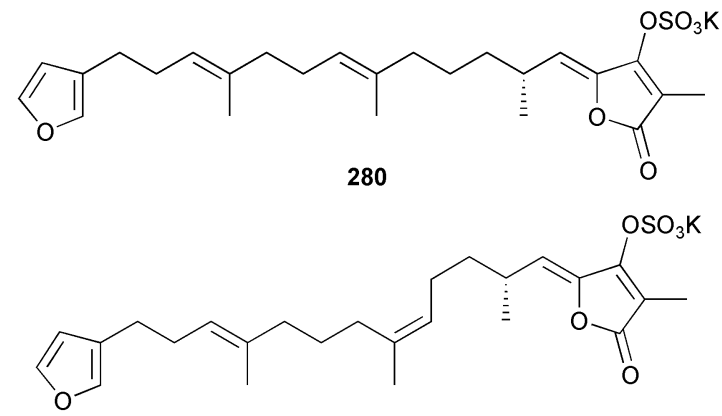

281<smiles>[X]OS(=O)(=O)OC1=C(C)C(=O)O/C1=C\[C@H](C)CCC/C(C)=C/CCc1coc(Cc2ccoc2)c1</smiles>

282<smiles>[R16]OS(=O)(=O)OC1=C(C)C(=O)O/C1=C\[C@H](C)CC/C=C(/C)CCCc1coc(Cc2ccoc2)c1</smiles>

3.3.10 Esters of sesterterpenoids. (18R)-Variabilin-11-methyloctadecanoate ester $\mathbf{2 8 9}$ has been isolated from the sponge Ircinia fefix from Colombia. ${ }^{197}$ The same sponge has yielded nine novel fatty acid esters, $(7 E, 12 E, 18 R, 20 Z)$-variabilin 
<smiles>CC1=CCCC(C)C1(C)CC/C(C)=C/CCC(C)CCCc1ccoc1</smiles>

284<smiles>CC(=O)O[C@H]1C/C(=C\CC[C@H](C)/C=C/C=C(\C)CCCc2ccoc2)OC1=O</smiles>

285<smiles>CC(=CC=C[C@@H](C)CCC[C@H](C)C=C1OC(=O)C(C)=C1OS(C)(=O)=O)CCCc1ccoc1</smiles>

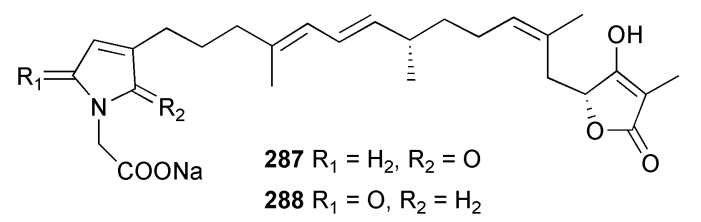

(5Z,9Z)-22-methyltricosadienoate, $(7 E, 12 E, 18 R, 20 Z)$-variabilin $(5 Z, 9 Z)$-tetracosadienoate, $(7 E, 12 E, 18 R, 20 Z)$-variabilin hexadecanoate, $(7 E, 12 E, 18 R, 20 Z)$-variabilin 10-methylhexadecanoate, (7E,12E,18R,20Z)-variabilin 15-methylhexadecanoate, $(7 E, 12 E$, $18 R, 20 Z)$-variabilin 14-methylhexadecanoate, $(7 E, 12 E, 18 R, 20 Z)$ variabilin 9-octadecenoate, $(7 E, 12 E, 18 R, 20 Z)$-variabilin octadecanoate, and $(7 E, 12 E, 18 R, 20 Z)$-variabilin 2,11-dimethyloctadecanoate (290-298). ${ }^{198}$

\subsection{Furanotriterpenoids}

3.4.1 $\mathrm{C}_{30}$ terpenoids. $\mathrm{A}_{30}$ furanoterpene, furospinosulin 2299 , has been isolated from Ircinia spinosula. ${ }^{191}$ Three triterpenoids, viz. hydroxymokupalide 300, acetoxymokupalide 301, and mokupalide 302, have been obtained from a species of the genus Megalopastas. ${ }^{199,200}$ The structure of mokupalide 302 was confirmed by total synthesis. ${ }^{201}$<smiles>CC(C)=CCC/C(C)=C/CC/C(C)=C/CC/C(C)=C/CC/C(C)=C/CCc1ccoc1</smiles>

299<smiles>[R]C1OC(=O)C=C1CC/C=C(\C)CC/C=C(/C)CC/C=C(/C)CCC1=C(C)CCCC1(C)C</smiles>

$(Z, E, E)$-Cupaniopsin A, $(Z, E, Z)$-cupaniopsin A, the 29methyl ester of $(Z, E, E)$-cupaniopsin $\mathrm{A},(Z, E, Z)$-cupaniopsin C, 22-hydroxy-(Z,E,Z)-cupaniopsin C, 23-hydroxy-(Z,E,Z)cupaniopsin $\mathrm{C},(Z, E, Z)$-cupaniopsin A methyl ester, and $(Z, E, Z)$ cupaniopsin E (303-310) were isolated from the bark of Cupaniopsis trigonocarpa Radlk. \& Guillaumin, C. azantha Radlk. and C. phallacrocarpa F. Adema (Sapindaceae). Five of them exhibited potent binding activity on the peroxisome proliferator-activated receptor, the most potent being $(Z, E, E)$-cupaniopsin A 303. This is the first report of linear furanotriterpenes isolated from the plant kingdom. ${ }^{202}$

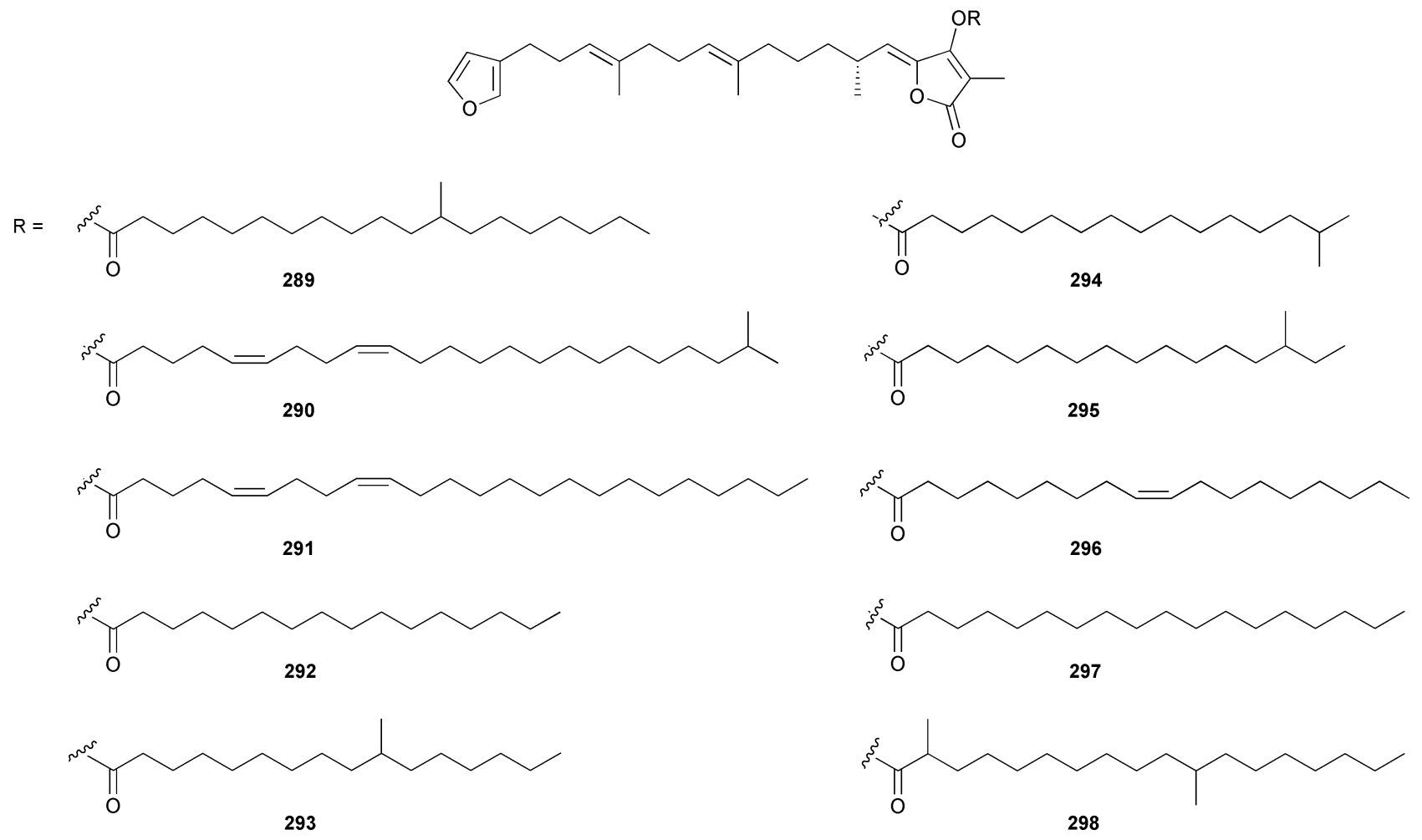


<smiles>[R20]OC(=O)C(=CCCc1ccoc1)CCC(CC=C(C)CCC=C([R3])CCC=C([R])[R])C(=C)C</smiles>

$30316 E \mathrm{R}_{1}=\mathrm{CH}_{3}, \mathrm{R}_{2}=\mathrm{CH}_{3}, \mathrm{R}_{3}=\mathrm{COOH}, \mathrm{R}_{4}=\mathrm{H}$

$30416 Z \mathrm{R}_{1}=\mathrm{CH}_{3}, \mathrm{R}_{2}=\mathrm{CH}_{3}, \mathrm{R}_{3}=\mathrm{COOH}, \mathrm{R}_{4}=\mathrm{H}$

$30516 E \mathrm{R}_{1}=\mathrm{CH}_{3}, \mathrm{R}_{2}=\mathrm{CH}_{3}, \mathrm{R}_{3}=\mathrm{COOH}, \mathrm{R}_{4}=\mathrm{CH}_{3}$

$30616 Z \mathrm{R}_{1}=\mathrm{CH}_{3}, \mathrm{R}_{2}=\mathrm{CH}_{3}, \mathrm{R}_{3}=\mathrm{CH}_{3}, \mathrm{R}_{4}=\mathrm{H}$

$30716 Z \mathrm{R}_{1}=\mathrm{CH}_{2} \mathrm{OH}, \mathrm{R}_{2}=\mathrm{CH}_{3}, \mathrm{R}_{3}=\mathrm{CH}_{3}, \mathrm{R}_{4}=\mathrm{H}$

$30816 Z \mathrm{R}_{1}=\mathrm{CH}_{3}, \mathrm{R}_{2}=\mathrm{CH}_{2} \mathrm{OH}, \mathrm{R}_{3}=\mathrm{CH}_{3}, \mathrm{R}_{4}=\mathrm{H}$

$30916 Z \mathrm{R}_{1}=\mathrm{CH}_{3}, \mathrm{R}_{2}=\mathrm{CH}_{3}, \mathrm{R}_{3}=\mathrm{COOH}, \mathrm{R}_{4}=\mathrm{CH}_{3}$

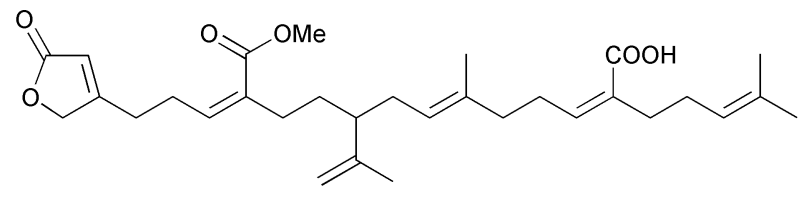

310

3.4.2 $\mathrm{C}_{31}$ terpenoids. It has been suggested that a $\mathrm{C}_{31}$ difuranoterpene, difurospinosulin 311 (isolated from Ircinia spinosula), could be derived from a $\mathrm{C}_{35}$ linear furanoterpene by the loss of four carbon atoms. ${ }^{191} \mathrm{~A} \mathrm{C}_{31}$ furanoterpene alcohol sulfate, named ircinol sulfate $\mathbf{3 1 2}$, has been isolated from a marine sponge, Ircinia sp., collected off New Caledonia. ${ }^{203}$ Ircinol sulfate is the second example of a $\mathrm{C}_{31}$ furanoterpene encountered in marine sponges.

3.4.3 $\mathrm{C}_{35}$ terpenoids. A linear $\mathrm{C}_{35}$ furanoterpene, furospinosulin3 313, has been isolated from Ircinia spinosula ${ }^{191}$

\section{Pyrroloterpenoids}

\subsection{Pyrrolosesquiterpenoids}

Pyrrolostatin 314, a lipid peroxidation inhibitor, was isolated from the culture of Streptomyces chrestomyceticus EC40. ${ }^{204}$ Pyrrolostatin inhibited lipid peroxidation in rat brain homogenate. A Streptomyces sp. (NPS008187) isolated from a marine sediment collected in Alaska was found to produce three pyrrolosesquiterpenes, glyciapyrroles A 315, B 316, and C 317. Glyciapyrrole A<smiles>CC(C)=CCC/C(C)=C/Cc1c[nH]c(C(=O)O)c1</smiles><smiles>CC(/C=C/C(O)C1(C)CCC(C(C)O)O1)=C\C(=O)c1ccc[nH]1</smiles><smiles>CC(C)=CCCC(C)(O)C(O)C=CC(C)=CC(=O)c1ccc[nH]1</smiles><smiles>CC(C)=CCCC1(C)OC1/C=C/C(C)=C\C(=O)c1ccc[nH]1</smiles>

inhibited both colorectal adenocarcinoma HT-29 and melanoma B16-F10 tumor cell growth. ${ }^{205}$

\subsection{Pyrrolosesterterpenoids and norsesterterpenoids}

The pyrrolosesterterpenes sarcotrines A 318, B 320, C 322, D 324, E 287 and F 218, epi-sarcotrines A 319, B 321 and

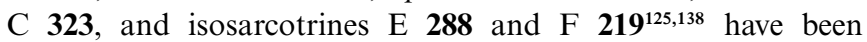
isolated from a marine sponge of the genus Sarcotragus. Two trinorsesterterpenoid lactams, sarcotragins A 208 and B 209, with structures similar to those of the sarcotrines, have been isolated from another Sarcotragus sponge collected from Jaeju Island in Korean waters. ${ }^{151}$ It is quite feasible that sarcotrines and sarcotragins share the same biogenetic precursor, and that the latter are the degradation products of the former. Two microbial metabolites of palinurin $\mathbf{2 2 0}^{155}$ (re-isolated from a Red Sea sponge, Ircinia echinata), palinurines A 325 and B 326, are produced by the fungus Cunninghamella sp. NRRL 5695. ${ }^{206}$ The possible transformation of furans to amides (viz. dehydro-3-enepyrrolidin2-one and dehydro-3-enepyrrolidin-5-one) through a biomimetic reaction is certain to have applications in synthetic chemistry.<smiles>CC(=CCCC(C)=CCCc1ccoc1)CCC=C(C)CCC=C(C)CCCc1ccoc1</smiles><smiles>CC(=CCCC(C)=CCCc1ccoc1)CCC=C(C)CCC=C(C)CCCC(C)CCOS(C)(=O)=O</smiles><smiles>CC(C)=CCC/C(C)=C/CC/C(C)=C/CC/C(C)=C/CC/C(C)=C/CC/C(C)=C/CCc1ccoc1</smiles> 


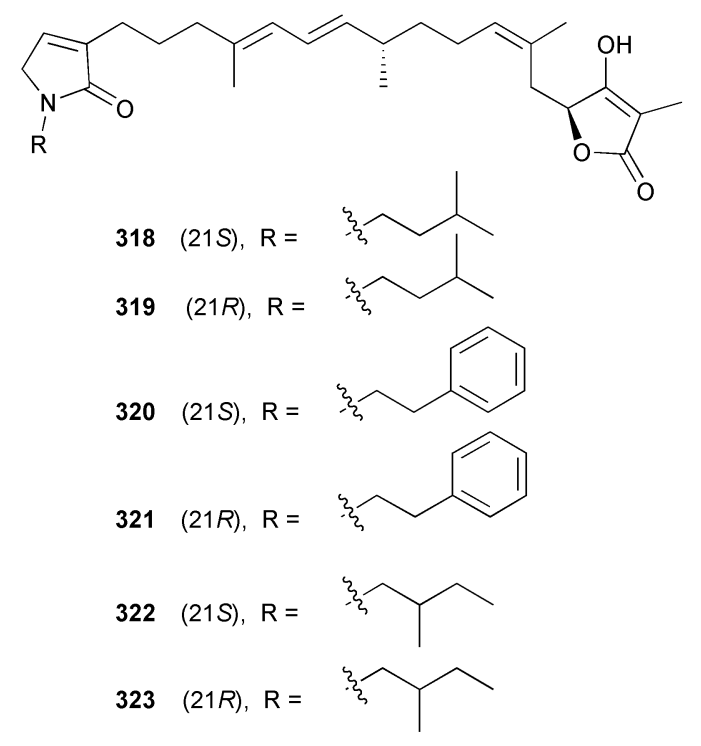<smiles>[R]CCCCCCCCC(C)=CC=C[C@@H](C)CCC=C(C)C[C@H]1OC(=O)C(C)=C1O</smiles><smiles>[R]c1cc(CCC/C(C)=C/C=C/[C@H](C)CC/C=C(\C)C[C@H]2OC(=O)C(C)=C2O)c([R2])n1[CH]CO</smiles>

$325 \mathrm{R}_{1}=\mathrm{H}_{2}, \mathrm{R}_{2}=\mathrm{O}$

$326 \mathrm{R}_{1}=\mathrm{O}, \mathrm{R}_{2}=\mathrm{H}_{2}$

\section{Acknowledgements}

We are grateful for a grant from the Hundred Talents Project of the Chinese Academy of Sciences.

\section{References}

1 B. M. Fraga, Nat. Prod. Rep., 2005, 22, 465, and earlier reviews cited therein.

2 J. R. Hanson, Nat. Prod. Rep., 2005, 22, 594, and earlier reviews cited therein.

3 J. R. Hanson, Nat. Prod. Rep., 1996, 13, 529, and earlier reviews cited therein.

4 J. D. Connolly and R. A. Hill, Nat. Prod. Rep., 2005, 22, 487, and earlier reviews cited therein.

5 D. J. Faulkner, Nat. Prod. Rep., 2002, 19, 1, and earlier reviews cited therein.

6 J. W. Blunt, B. R. Copp, M. H. G. Munro, P. T. Northcote and M. R. Prinsep, Nat. Prod. Rep., 2005, 22, 15, and earlier reviews cited therein.

7 S. P. Tanis, Tetrahedron Lett., 1982, 23, 3115.

8 S. Araki and Y. Butsugan, Chem. Lett., 1982, 177.

9 E. Lee, Y. H. Park and S. K. Park, Tetrahedron Lett., 1982, 23, 2671.

10 D. K. Barma, A. Kundu, R. Baati, C. Mioskowski and J. R. Falck, Org. Lett., 2002, 4, 1387.

11 R. W. Dunlop, R. Kazlauskas, G. March, P. T. Murphy and R. J. Wells, Aust. J. Chem., 1982, 35, 95.

12 G. Guella, A. Guerriero, P. Traldi and F. Pietra, Tetrahedron Lett., 1983, 24, 3897.

13 M. B. Ksebati and F. J. Schmitz, J. Nat. Prod., 1988, 51, 857.

14 P. L. Metra and M. D. Sutherland, Tetrahedron Lett., 1983, 24, 1749.

15 R. C. Anand and V. Singh, Tetrahedron, 1993, 49, 6515.

16 N. H. Tran, J. N. A. Hooper and R. J. Capon, Aust. J. Chem., 1995, 48, 1757.

17 K. Gerlach and H. M. R. Hoffmann, Synlett, 1998, 682.

18 L. T. Burka, L. Kuhnert, B. J. Wilson and T. M. Harris, Tetrahedron Lett., 1974, 15, 4017.

19 E. Dimitriadis and R. A. Massy-Westropp, Phytochemistry, 1984, 23, 1325.

20 L. F. Tietze, C. Wegner and C. Wulff, Chem.-Eur. J., 1999, 5, 2885.

21 R. J. Clark, M. J. Garson, I. M. Brereton and J. A. Kennedy, J. Nat. Prod., 1999, 62, 915.

22 M. I. Ybarra, C. A. N. Catalan, J. Diaz and W. Herz, Phytochemistry, 1994, 35, 1585.

23 J. A. Schneider, J. Lee, Y. Naya, K. Nakanishi, K. Oba and I. Uritani, Phytochemistry, 1984, 23, 759.

24 A. Fontana, C. Avila, E. Martinez, J. Ortea, E. Trivellone and G. Cimino, J. Chem. Ecol., 1993, 19, 339.

25 L. A. Lenis, M. J. Ferreiro, C. Debitus, C. Jiménez, E. Quiñoa and R. Riguera, Tetrahedron, 1998, 54, 5385.

26 A. Fontana, C. Muniain and G. Cimino, J. Nat. Prod., 1998, 61, 1027.

27 Y. M. Syah, E. M. Ghisalberti, B. W. Skelton and A. H. White, J. Nat. Prod., 1997, 60, 49.

28 B. F. Bowden, J. C. Coll, E. D. de Silva, M. S. L. de Costa, P. J. Djura, M. Mahendran and D. M. Tapiolas, Aust. J. Chem., 1983, 36, 371.

29 F. Bohlmann, C. Zdero, R. M. King and H. Robinson, Phytochemistry, 1983, 22, 2863.

30 D. H. Williams and D. J. Faulkner, Tetrahedron, 1996, 52, 4245.

31 G. Cimino, S. de Rosa, S. de Stefano and G. Sodano, J. Nat. Prod., $1984,47,877$.

32 A. S. R. Anjaneyulu, N. S. K. Rao and M. J. R. V. Venugopal, Indian J. Chem., Sect. B: Org. Chem. Incl. Med. Chem., 1996, 35, 1001.

33 M. R. Kim, H. J. Jung, B. S. Min, S. R. Oh, C. S. Kim, K. S. Ahn, W. S. Kang and H. K. Lee, Phytochemistry, 2002, 59, 861.

34 R. N. Baruah, F. Bohlmann and R. M. King, Planta Med., 1985, 531.

35 S. K. Park and P. J. Scheuer, J. Korean Chem. Soc., 1994, 38, 749.

36 S. Mizobuchi, K. Kon-ya, K. Adachi, M. Sakai and W. Miki, Fish Sci., 1994, 60, 345.

37 K. L. McPhail, M. T. Davies-Coleman and J. Starmer, J. Nat. Prod., $2001,64,1183$.

38 C. W. Jefford, J.-C. Rossier, J. Boukouvalas, A. W. Sledeski and P.-Z. Huang, J. Nat. Prod., 2004, 67, 1383.

39 B. Sullivan, D. J. Faulkner and L. Webb, Science, 1983, 221, 1175.

40 J. E. Hochlowski and D. J. Faulkner, Tetrahedron Lett., 1981, 22, 271.

41 D. W. Knight and D. C. Rustidge, J. Chem. Soc., Perkin Trans. 1, 1981, 679.

42 F. Tsichritzis, J. Jakupovic and F. Bohlmann, Phytochemistry, 1990, 29, 195.

43 V. Castro, J. Jakupovic and F. Bohlmann, J. Nat. Prod., 1984, 47, 802.

44 T. Fujita, Y. Takaishi, Y. Takeda, T. Fujiyama and T. Nishi, Chem. Pharm. Bull., 1984, 32, 4419.

45 J. A. Marco, J. F. Sanz-Cervera, F. Sancenon, M. Arno and J. VallesXirau, Phytochemistry, 1994, 37, 1095.

46 S. M. Khafagy, M. A. Al-Yahya, J. Ziesche and F. Bohlmann, Phytochemistry, 1983, 22, 1821.

47 L. N. Misra, A. Chandra and R. S. Thakur, Phytochemistry, 1991, 30, 549.

48 M. Miski, T. J. Mabry and F. Bohlmann, J. Nat. Prod., 1986, 49, 916.

49 G. Ruecker, E. Breitmaier, R. Mayer and D. Manns, Arch. Pharm. (Weinheim, Ger.), 1987, 320, 437.

50 G. Ruecker, D. Manns and S. Wilbert, Arch. Pharm. (Weinheim, Ger.), 1993, 326, 457.

51 J. De Pascual-Teresa, S. Vicente, M. S. Gonzalez and I. S. Bellido, Phytochemistry, 1983, 22, 2235.

52 K. Jenett-Siems, K. Siems, L. Witte and E. Eich, J. Nat. Prod., 2001, 64, 1471. 
53 R. M. Carman, P. N. Handley, R. Kadirvelraj, W. T. Robinson and M. D. Sutherland, Aust. J. Chem., 1999, 52, 727.

54 D. J. Gochfeld and M. T. Hamann, J. Nat. Prod., 2001, 64, 1477.

55 C. Menut, P. Cabalion, E. Hnawia, H. Agnaniet, J. Waikedre and A. Fruchier, Flavour Fragrance J., 2005, 20, 621.

56 A. Fontana, M. Gavagnin, E. Mollo, E. Trivellone, J. Orteat and G. Cimino, Comp. Biochem. Physiol., B: Biochem. Mol. Biol., 1995, 111, 283.

57 L. Lehmann, J. Jakupovic, F. Bohlmann, R. M. King and L. Haegi, Phytochemistry, 1988, 27, 2994.

58 H. Gaspar, M. Gavagnin, G. Calado, F. Castelluccio, E. Mollo and G. Cimino, Tetrahedron, 2005, 61, 11032.

59 S. Potvin and P. Canonne, Tetrahedron: Asymmetry, 1996, 7, 2821.

60 G. Cimino, S. De Stefano, A. Guerriero and L. Minale, Tetrahedron Lett., 1975, 43, 3723.

61 G. Cimino, S. De Rosa, S. De Stefano, R. Morrone and G. Sodano, Tetrahedron, 1985, 41, 1093.

62 J. Hellou, R. J. Andersen and J. E. Thompson, Tetrahedron, 1982, 38, 1875.

63 Z. Y. Shao, Y. H. Zhang, J. N. Li, K. J. Jiang and B. K. Kuai, Z. Naturforsch., C: Biosci., 2004, 59, 181.

64 J. C. Coll, B. F. Bowden, D. M. Tapiolas, R. H. Willis, P. Djura, M. Streamer and L. Trott, Tetrahedron, 1985, 41, 1085.

65 K. Kojima, K. Isaka, O. Purev, G. Jargalsaikhan, D. Suran, H. Mizukami and Y. Ogihara, Chem. Pharm. Bull., 1998, 46, 1781.

66 A. Fürstner and T. Gastner, Org. Lett., 2000, 2, 2467.

67 L. Zechlin, M. Wolf, W. Steglich and T. Anke, Liebigs Ann. Chem., 1981, 2099.

68 S. Faure, J. D. Connolly, C. O. Fakunle and O. Piva, Tetrahedron, 2000, 56, 9647 .

69 K. Kojina, K. Isaka, O. Purev, G. Jargalsaikhan, D. Suran, H. Mizukami and Y. Ogihara, Chem. Pharm. Bull., 1999, 47, 690.

70 K. Kojima, K. Isaka, P. Ondognii, O. Zevgeegiin, K. Davgiin, H. Mizukami and Y. Ogihara, Chem. Pharm. Bull., 1999, 47, 1145.

71 T. Motai, A. Daikonya and S. Kitanaka, J. Nat. Prod., 2004, 67, 432.

72 T. Motai and S. Kitanaka, Chem. Pharm. Bull., 2004, 52, 1215.

73 A. Nagatsu, K. Isaka, K. Kojima, P. Ondognii, O. Zevgeegiin, P. Gombosurengyin, K. Davgiin, B. Irfan, C. M. Iqubal and Y. Ogihara, Chem. Pharm. Bull., 2002, 50, 675.

74 T. Motai and S. Kitanaka, J. Nat. Prod., 2005, 68, 365.

75 H. Yoda, K. Maruyama and K. Takabe, Tetrahedron Lett., 2003, 44, 1775

76 B.-N. Su, Y. Takaishi, G. Honda, M. Itoh, Y. Takeda, O. K. Kodzhimatov and O. Ashurmetov, J. Nat. Prod., 2000, 63, 436.

77 B.-N. Su, Y. Takaishi, G. Honda, M. Itoh, Y. Takeda, O. K. Kodzhimatov and O. Ashurmetov, J. Nat. Prod., 2000, 63, 520.

78 F. Bohlmann and R. K. Gupta, Phytochemistry, 1982, 21, 1309.

79 F. Bohlmann and C. Zdero, Phytochemistry, 1982, 21, 1989.

80 K. A. Dastlik, P. G. Foster, E. L. Ghisalberti and P. R. Jefferies, Phytochemistry, 1989, 28, 1425.

81 J. Jakupovic, U. Ganzer, P. Pritschow, L. Lehmann, F. Bohlmann and R. M. King, Phytochemistry, 1992, 31, 863.

82 C. A. Russell and M. D. Sutherland, Aust. J. Chem., 1982, 35, 1881.

83 L. T. Burka and A. Thorsen, Phytochemistry, 1982, 21, 869.

84 J. A. Schneider, K. Yoshihara and K. Nakanishi, J. Chem. Soc., Chem Commun., 1983, 352.

85 Y. Oshima, K. Tanaka and H. Hikino, Phytochemistry, 1993, 33, 233.

86 I. Ito, N. Kato and I. Uritani, Agric. Biol. Chem., 1984, 48, 159.

87 A. San Martin, J. Rovirosa, C. Xu, H. S. M. Lu and J. Clardy, Tetrahedron Lett., 1987, 28, 6013.

88 G. Bojack and H. Bornowski, Tetrahedron, 1991, 47, 9179.

89 A. Gaebler, W. Boland, U. Preiss and H. Simon, Helv. Chim. Acta, 1991, 74, 1773.

90 R. S. Kalidindi, W. Y. Yoshida, J. A. Palermo, P. J. Sheuer and M. Kelly-Borges, Tetrahedron Lett., 1994, 35, 5579.

91 J. A. Marco, J. F. Saenz-Cervera, V. Garcia-Lliso, M. Guara and J. Valles-Xirau, Phytochemistry, 1997, 45, 751.

92 C. Zdero, L. Lehmann and F. Bohlmann, Phytochemistry, 1991, 30, 1161.

93 A. Ortega, J. C. Lopez and E. Maldonado, Phytochemistry, 1989, 28, 2735.

94 J. A. Marco, J. F. Sanz-Cervera and G. Ocete, J. Nat. Prod., 1994, 57, 939.

95 F. Bohlmann, T. V. Chau-Thi, P. Singh and J. Jakupovic, Planta Med., 1985, 487.
96 A. A. L. Gunatilaka, B. Dhanabalasingham, L. Paredes, J. Jakupovic, F. Bohlmann and N. K. B. Adikaram, Phytochemistry, 1987, 26, 2408.

97 J. R. Saad, M. J. Pestchanker and O. S. Giordano, Phytochemistry, 1987, 26, 3033.

98 C. Zdero, F. Bohlmann and H. M. Niemeyer, Phytochemistry, 1990, 29, 1227.

99 L. Hougaard, U. Anthoni, C. Christopherson and P. H. Nielsen, Phytochemistry, 1991, 30, 3049.

100 P. A. Searle and T. F. Molinski, Tetrahedron, 1994, 50, 9893.

101 R. Valls, L. Piovetti, B. Banaigs, A. Archavlis and M. Pellegrini, Phytochemistry, 1995, 39, 145.

102 S. Urban and R. J. Capon, Aust. J. Chem., 1995, 48, 1903.

103 E. P. Schenkel, A. M. Sobottka, P. P. Lankhorst and J. Schripsema, Phytochemistry, 1997, 44, 755.

104 A. M. Galal, E. Abdel-Sattar, F. S. El-Feraly, J. S. Massa, M. R. Meselhy, S. Kadota and T. Nambo, Phytochemistry, 1998, 48, 159.

105 E. Abdel-Sattar, Monatsh. Chem., 2001, 132, 1095.

106 G. Culioli, M. Daoudi, V. Mesguiche, R. Valls and L. Piovetti, Phytochemistry, 1999, 52, 1447.

107 S. De Rosa, R. Puliti, A. Crispino, A. De Giulio, C. De Sena, C. Jodice and C. A. Mattia, Tetrahedron, 1995, 51, 10731.

108 C. Zdero, F. Bohlmann and G. M. Mungai, Phytochemistry, 1991, 30, 575.

109 M. Gavagnin, A. Spinella, A. Crispino, R. De Almeida Epifanio, A. Marin and G. Cimino, Gazz. Chim. Ital., 1993, 123, 205.

110 R. Valls, L. Piovetti and A. Praud, Hydrobiologia, 1993, 260, 549.

111 F. E. Koehn, S. P. Gunasekera, D. N. Niel and S. C. Cross, Tetrahedron Lett., 1991, 32, 169.

112 B. Y. Hwang, J. H. Lee, J. B. Nam, H. S. Kim, Y. S. Hong and J. J. Lee, J. Nat. Prod., 2002, 65, 616.

113 M. Bittner, A. Schuster and J. Jakupovic, Phytochemistry, 1991, 30, 1329.

114 S. Yu, M. F. Wang, C.-T. Ho, C.-K. Chin, S.-W. Yang, G. A. Cordell, H. Lotter and H. Wagner, Phytochemistry, 1998, 49, 609.

115 E. Maldonado, M. Bello, J. L. Villasenor and A. Ortega, Phytochemistry, 1998, 49, 1115.

116 S. Zheng, J. Wang, J. Lu, T. Shen, L. Sun and X. Shen, Planta Med., 2000, 66, 487.

117 M. Toyota, F. Nagashima and Y. Asakawa, Phytochemistry, 1989, 28, 1661.

118 S. Yahara, Y. Izumitani and T. Nohara, Tennen Yuki Kagobutsu Toronkai Koen Yoshishu, 1988, 30, 173.

119 L. Quijano, F. R. Fronczek and N. H. Fischer, Phytochemistry, 1985, 24, 1747.

120 J. X. Wang, S. Z. Zheng, L. P. Sun, X. W. Shen and Y. Li, J. Chin. Chem. Soc. (Taipei, Taiwan), 2002, 49, 437.

121 D. Tasdemir, M. K. Harper, G. P. Concepcion, G. C. Mangalindan, E. Hajdu and C. M. Ireland, Tetrahedron, 2000, 56, 9025.

122 E. Wollenweber, M. Dorr, M. Dorsam, A. El-Hamed Hassan, A. A. Ahmed, M. F. Hegazy and K. P. Zeller, Z. Naturforsch., C: Biosci., 2003, 58, 153

123 J. Carroll, E. N. Jonsson, R. Ebel, M. S. Hartman, T. R. Holman and P. Crews, J. Org. Chem., 2001, 66, 6847.

124 C. A. Ospina, A. D. Rodriguez, J. A. Sanchez, E. Ortega-Barria, T. L. Capson and M. S. Mayer, J. Nat. Prod., 2005, 68, 1519.

125 Y. Liu, J. Hong, C.-O. Lee, K. S. Im, N. D. Kim, J. S. Choi and J. H. Jung, J. Nat. Prod., 2002, 65, 1307.

126 E. Fattorusso, L. Minale, G. Sodano and E. Trivellone, Tetrahedron, 1971, 27, 3909

127 G. Cimino, S. de Stefano, L. Minale and E. Fattorusso, Tetrahedron, 1972, 28, 267.

128 G. Cimino, S. de Stefano, L. Minale and E. Fattorusso, Tetrahedron, 1971, 27, 4673.

129 R. J. Capon, E. L. Ghisalberti and P. R. Jefferies, Experientia, 1982, 38, 1444.

130 Y. Kashman and M. Zviely, Experientia, 1980, 36, 1179.

131 G. Guella, P. Amande and F. Pietra, Helv. Chim. Acta, 1986, 69, 726.

132 J. Tanaka and T. Higa, Tetrahedron, 1988, 44, 2805.

133 A. Umeyama, N. Shoji, S. Arihara, Y. Ohizumi and J. Kobayashi, Aust. J. Chem., 1989, 42, 459.

134 F. J. Schmitz and J. C. Chang, J. Nat. Prod., 1988, 51, 745.

135 J. Kobayashi, H. Shinonega, H. Shigemori and T. Sasaki, Chem. Pharm. Bull., 1993, 41, 381.

136 L. A. Lenis, L. Nunez, C. Jimenez and R. Riguera, Nat. Prod. Lett., $1996,8,15$. 
137 G. Guella, I. Mancini, I. N'Diaye and F. Pietra, Tetrahedron Lett., 1991, 32, 6415.

138 Y. Liu, T. A. Mansoor, J. Hong, C.-O. Lee, C. J. Sim, K. S. Im, N. D. Kim and J. H. Jung, J. Nat. Prod., 2003, 66, 1451.

139 Y. W. Guo and E. Trivellone, Chin. Chem. Lett., 2000, 11, 327.

140 A. Fontana, L. Albarella, G. Scognamiglio, M. Uriz and G. Cimino, J. Nat. Prod., 1996, 59, 869.

141 M. Kobayashi, R. Chavakula, O. Murata and N. S. Sarma, Chem. Pharm. Bull., 1992, 40, 599.

142 T. Bando and K. Shishido, Chem. Commun., 1996, 1357.

143 L. Garrido, E. Zubía, M. J. Ortega and J. Salvá, J. Nat. Prod., 1997, 60, 794.

144 R. J. Capon, A. Jenkins, F. Rooney and E. L. Ghisalberti, J. Nat. Prod., 2001, 64, 638.

145 G. Cimino, S. De Stefano and L. Minale, Tetrahedron, 1972, 28, 5983.

146 A. G. Gonzalez, M. L. Rodriguez and A. S. M. Barrientos, J. Nat. Prod., 1983, 46, 256.

147 A. Fürstner, T. Gastner and J. Rust, Synlett, 1999, 29.

148 R. Kazlauskas, P. T. Murphy and R. J. Wells, Experientia, 1980, 36, 814.

149 L. Chill, A. Rudi, M. Aknin, S. Loya, A. Hizi and Y. Kashman, Tetrahedron, 2004, 60, 10619.

150 S. J. Rochfort, D. Atkin, L. Hobbs and R. J. Capon, J. Nat. Prod., 1996, 59, 1024.

151 J. Shin, J. R. Rho, Y. Seo, H. S. Lee, K. W. Cho and C. J. Sim, Tetrahedron Lett., 2001, 42, 3005.

152 I. N'Diaye, G. Guella, I. Mancini, J. M. Kornprobst and F. Pietra, J. Chem. Soc., Chem. Commun., 1991, 97.

153 A. De Giulio, S. De Rosa, G. D. Vincenzo, G. Strazzullo and N. Zavodnik, J. Nat. Prod., 1990, 53, 1503.

154 H. H. Issa, J. Tanaka and T. Higa, J. Nat. Prod., 2003, 66, 251.

155 G. Alfano, G. Cimino and S. de Stefano, Experientia, 1979, 35, 1136.

156 L. V. Manes, P. Crews, M. B. Ksebati and F. J. Schmitz, J. Nat. Prod., 1986, 49, 787.

157 M. Ortiz-Garcia and A. D. Rodriguez, Tetrahedron, 1990, 46, 1119.

158 V. Liokas, M. J. Garson and J. A. Carver, Aust. J. Chem., 1989, 42, 1805.

159 Y. Kato, N. Fusetani, S. Matsunaga and K. Hashimoto, Chem. Lett., $1985,1521$.

160 Y. Kato, N. Fusetani, S. Matsunaga and K. Hashimoto, Experientia, 1986, 42, 1299.

161 J. Kobayashi, Y. Ohizumi, H. Nakamura and Y. Hirata, Tetrahedron Lett., 1986, 27, 2113.

162 W. D. Schmitz, N. B. Messerschmidt and D. Romo, J. Org. Chem., 1998, 63, 2058.

163 L. Murray, H. Hamit, J. N. A. Hooper, L. Hobbs and R. J. Capon, Aust. J. Chem., 1995, 48, 1899.

164 L. Murray, A. T. R. Sim, J. A. P. Rostas and R. J. Capon, Aust. J. Chem., 1993, 46, 1291.

165 S. Urban and R. J. Capon, Aust. J. Chem., 1992, 45, 1255.

166 Y. Liu, B. H. Bae, N. Alam, J. Hong, C. J. Sim, C. Lee, K. S. Im and J. H. Jung, J. Nat. Prod., 2001, 64, 1301.

167 K. Choi, J. Hong, C.-O. Lee, D. Kim, C. J. Sim, K. S. Im and J. H Jung, J. Nat. Prod., 2004, 67, 1186.

168 G. Cimino, S. de Stefano, L. Minale and E. Fattorusso, Tetrahedron, 1972, 28, 333.

169 D. J. Faulkner, Tetrahedron Lett., 1973, 14, 3821.

170 I. Rothberg and P. Shubiak, Tetrahedron Lett., 1975, 16, 769.

171 F. Cafieri, E. Fattorusso, C. Santacroce and L. Minale, Tetrahedron, 1972, 28, 1579.
172 C. J. Barrow, J. W. Blunt, M. H. G. Munro and N. B. Perry, J. Nat. Prod., 1988, 51, 275.

173 M. Kernan, R. C. Cambie and P. R. Bergquist, J. Nat. Prod., 1991, 54, 265.

174 C. J. Barrow, J. W. Blunt, M. H. G. Munro and N. B. Perry, J. Nat. Prod., 1988, 51, 1294.

175 C. J. Barrow, J. W. Blunt and M. H. G. Munro, J. Nat. Prod., 1989, 52, 346.

176 M. R. Kernan and D. J. Faulkner, J. Org. Chem., 1988, 53, 2773.

177 M. Ishibashi, M. Kurosaki, Y. Mikami and J. Kobayashi, Nat. Prod. Lett., 1993, 3, 189.

178 R. J. Capon, T. R. Dargaville and R. Davis, Nat. Prod. Lett., 1994, 4, 51.

179 A. Martinez, C. Duque, N. Sato, R. Tanaka and Y. Fujimoto, Nat. Prod. Lett., 1995, 6, 1.

180 R. Davis and R. J. Capon, Aust. J. Chem., 1994, 47, 933.

181 A. Martínez, C. Duque, N. Sato and Y. Fujimoto, Chem. Pharm. Bull., $1997, \mathbf{4 5}, 181$.

182 U. Höller, G. M. König and A. D. Wright, J. Nat. Prod., 1997, 60, 832.

183 K. Takabe, H. Hashimoto, H. Sugimoto, M. Nomoto and H. Yoda, Tetrahedron: Asymmetry, 2004, 15, 909.

184 Y. H. Jiang, S.-H. Ryu, E.-Y. Ahn, S. You, B.-J. Lee, J. H. Jung and D.-K. Kim, Nat. Prod. Sci., 2004, 10, 272.

185 K. McPhail, M. T. Davies-Coleman and P. Coetzee, J. Nat. Prod., 1998, 61, 961

186 R. P. Walker, J. E. Thompson and D. J. Faulkner, J. Org. Chem., 1980, 45, 4976.

187 Y. Noda, H. Hashimoto and T. Norizuki, Heterocycles, 2001, 55, 1839.

188 E. Fattorusso, V. Lanzotti, S. Magno, L. Mayol, M. DiRosa and A. Ialenti, Bioorg. Med. Chem. Lett., 1991, 1, 639.

189 M.-L. Bourguet-Kondracki, C. Debitus and M. Guyot, J. Chem. Res. (S), 1996, 192.

190 S. De Rosa, A. De Giulio, A. Crispino, C. Iodice and G. Tommonaro, Nat. Prod. Lett., 1997, 10, 267.

191 G. Cimino, S. De Stefano and L. Minale, Tetrahedron, 1972, 28, 1315.

192 M. Tsoukatou, H. Siapi, C. Vagias and V. Roussis, J. Nat. Prod., 2003, 66, 444.

193 M. S. Butler and R. J. Capon, Aust. J. Chem., 1992, 45, 1705.

194 S. De Rosa, A. Milone, A. De Giulio, A. Crispino and C. Iodice, Nat. Prod. Lett., 1996, 8, 245.

195 M. R. Kernan and D. J. Faulkner, J. Org. Chem., 1988, 53, 4574.

196 S. De Rosa, A. De Giulio, A. Crispino, C. Iodice and G. Tommonaro, Nat. Prod. Lett., 1997, 10, 7.

197 A. Martinez, C. Dunque, N. Hara and Y. Fujimoto, Nat. Prod. Lett., $1995,6,281$

198 A. Martínez, C. Duque and Y. Fujimoto, Lipids, 1997, 32, 565.

199 M. B. Yunker and P. J. Scheuer, J. Am. Chem. Soc., 1978, 100, 307.

200 E. D. de Silva and P. J. Scheuer, Tetrahedron Lett., 1980, 21, 1611.

201 F. W. Sum and L. Weiler, J. Am. Chem. Soc., 1979, 101, 4401.

202 H. Bousserouel, M. Litaudon, B. Morleo, M.-T. Martin, O. Thoison, O. Nosjean, J. A. Boutin, P. Renard and T. Sevenet, Tetrahedron, 2005, 61, 845 .

203 G. Bifulco, I. Bruno, L. Minale, R. Riccio, C. Debitus, G. Bourdy, A. Vassas and J. Lavayre, J. Nat. Prod., 1995, 58, 1444.

204 S. Kato, K. Shindo, H. Kawai, A. Odagawa, M. Matsuoka and J. Mochizuki, J. Antibiot., 1993, 46, 892.

205 V. R. Macheria, J. Liu, C. Bellows, S. Teisan, B. Nicholson, K. S. Lam and B. C. M. Potts, J. Nat. Prod., 2005, 68, 780.

206 K. A. E. Sayed, A. M. S. Mayer, M. Kelly and M. T. Hamann, J. Org. Chem., 1999, 64, 9258. 